\title{
Raport „Alego" z akcji na Kutschere, czyli czego nie powiedział dowódca batalionu „Parasol”
}

Na początku 1946 r. ukazał się w piśmie „Życie Literackie” artykuł Bolesława Srockiego Twórczość literacka a rzeczywistość wojenna. Na marginesie literackich opracowań zamachu na gen. Kutscherę. Tekst Srockiego był odpowiedzią na artykuły dotyczące akcji zlikwidowania 1 lutego 1944 r. dowódcę SS (Schutzstaffel) i policji na dystrykt warszawski przez żołnierzy I plutonu kompanii „Pegaz” - oddziału dyspozycyjnego Kedywu Komendy Głównej Armii Krajowej, które ukazały się pod koniec 1945 r., czyli niespełna dwa lata po wydarzeniach ${ }^{1}$. Wycinki artykułów przesyłała Srockiemu Wanda Pietraszewiczowa - matka „Lota”, dowódcy akcji, który zmarł w wyniku ran odniesionych 1 lutego, prosząc „pana Bolesława” o interwencję. Szczególne oburzenie najbliższych uczestników akcji wywołał quasi-reportaż Wojciecha Żukrowskiego ze świątecznego numeru „Dziennika Zachodniego” pt. Wielkie łowy w Alejach Ujazdowskich. Nie chodziło o pomieszanie osób, pseudonimów, zdarzeń..., które pokazuje, jak w istocie niewiele wiedziano o przebiegu już wtedy legendarnej akcji, ale o ideowe oblicze żołnierzy wykonujących wyrok na „kacie Warszawy” nakreślone piórem Żukrowskiego. $\mathrm{Na}$ naświetleniu tego ideowego zaplecza skupił się Srocki, kwestie merytoryczne, ustalenie faktów odkładając na później i wyrażając przekonanie, że „o te szczegóły historia upomni się zapewne, lecz będzie w stanie sprostować je na podstawie suchych relacji urzędowych"2. Nie mylił się w tej materii ideowy opiekun okupacyjnego „Petu”, którego wychowankowie wykonali

\footnotetext{
1 Przedruk artykułu Srockiego zob. W. Stopczyński, W kręgu Bolesława Srockiego. Ludzie „Petu”. Relacje - wspomnienia - polemiki, Gdańsk 2016, s. 397. Tam również przedstawiono okoliczności powstania tekstu.
}

2 Ibidem, s. 399. 
akcję 1 lutego 1944 r., ale zapewne nie przypuszczał, że przeszło siedemdziesiąt lat czekać trzeba będzie, aż wszystkie „relacje urzędowe” ujrzą światło dzienne. Dzisiaj, kiedy od niedawna znamy te "relacje urzędowe”, trzeba postawić pytanie, co takiego na przestrzeni siedemdziesięciu lat stało się lub nie stało się - że narracja oparta na wypowiedziach uczestników akcji, którym udało się przeżyć wojnę, tak dalece odbiegła w istotnych szczegółach od tego, co zapisano w dokumentach powstałych tuż po akcji.

\section{Relacje}

W walce stoczonej w Alejach Ujazdowskich 1 lutego 1944 r. wzięło udział dziewięciu żołnierzy. Dwóch z nich - „Juno” (Zbigniew Gęsicki) oraz "Sokół” (Kazimierz Sott) - zginęło jeszcze tego samego dnia - zablokowani na moście Kierbedzia, po krótkiej walce skoczyli do Wisły. Dwóch kolejnych - „Lot” (dowódca akcji - Bronisław Pietraszewicz) i „Cichy” (Marian Senger) - zmarło $\mathrm{w}$ dniach następnych $\mathrm{z}$ ran odniesionych $\mathrm{w}$ walce. Zastępca „Lota” - „Ali” (Stanisław Huskowski) - zginął 11 lipca 1944 r. podczas odwrotu po nieudanej akcji na gen. Wilhelma Koppego w Krakowie. Losy dwóch innych rannych potoczyły się inaczej. „Olbrzymek” (Henryk Humięcki) po wyleczeniu ran wrócił do oddziału. Zginął w powstaniu warszawskim 27 sierpnia. W powstaniu wziął udział także „Bruno” (Bronisław Hellwig). Wcześniej, w maju 1944 r. podczas dramatycznej akcji na Waltera Stamma, otrzymał ciężki postrzał w głowę. Niedługo po wojnie, z powodu silnych bólów zdecydował się na operację, której nie przeżył. Bez szwanku wyszedł z akcji „Kruszynka” (Zdzisław Poradzki). Po wojnie wstąpił do Polskiej Partii Robotniczej (PPR), został awansowany do stopnia majora oraz otrzymał z rąk gen. Mariana Spychalskiego Order Wojenny Virtuti Militari właśnie za akcję na Franza Kutscherę ${ }^{3}$.

Trzecia rocznica akcji stała się okazją do publikacji w „Rzeczpospolitej” jego wspomnienia $\mathrm{z}$ wydarzeń 1 lutego $1944 \mathrm{r}^{4}$ Jest to jedyna relacja uczestnika akcji, która ukazała się drukiem przed rokiem 1956. „Kruszynka” zmarł w Poznaniu w maju 1952 r., nie doczekawszy październikowego przełomu. Jeszcze w pisanej w połowie lat pięćdziesiątych książce Romana Bratnego Kolumbowie rocznik 20. Poradzki był nazywany „jedynym z żyjących uczestników zamachu na Kutscherę"5. Nie było to prawdą.

\footnotetext{
3 „Kruszynka” miał po akcji zgłaszać dowódcy „Pegaza” pretensje, że nie otrzymał Orderu Wojennego Virtuti Militari, zob. M. Dylawerska et al., Akcja na Kutschere, „Wojskowy Przegląd Historyczny" (dalej: WPH) 1959, nr 4, s. 117.

4 Z. Poradzki, Zamach na Kutschere, „Rzeczpospolita”, 9-11 II 1947.

5 R. Bratny, Kolumbowie rocznik 20, Warszawa 2016, s. 573.
} 
„Miś" (Michał Issajewicz) został 1 lutego postrzelony w głowę - jak się okazało niegroźnie. W kwietniu $1944 \mathrm{r}$. aresztowano go podczas najścia Niemców na lokal konspiracyjny Józefa Szczepańskiego „Ziutka” przy ul. Długiej. Nierozpoznany, po krótkim śledztwie i pobycie na Pawiaku, został wysłany do KL Stutthof. Przeżył wojnę, wyjechał najpierw do Wejherowa, później do Słupska, by w 1947 r. wrócić do Warszawy. Także wstąpił do PPR, ale wybrał odmienną niż „Kruszynka” strategię - nie afiszował się ze swoją wojenną przeszłością tak ostentacyjnie. Nie składał i nie publikował żadnych relacji. Jego czas przyszedł po Październiku, kiedy „Miś” pozostał jedynym żyjącym uczestnikiem walki stoczonej 1 lutego 1944 r. i jedynym narratorem mającym legitymację, żeby o tej walce opowiadać. W 1958 r. ukazała się w mającej zyskać wielką popularność serii „Żółty Tygrys”, oparta przede wszystkim na ustnej relacji „Misia”, książka Marka Dunina-Wąsowicza Zamach na Kutscherę. Już rok wcześniej, w opracowaniu tego samego autora, w młodzieżowym czasopiśmie „Przygoda” ukazała się seria autoryzowanych wspomnień Michała Issajewicza ${ }^{6}$. W 1958 r. „Mis'” konsultował od strony historycznej film Jerzego Passendorfera Zamach. Ten - swoją drogą świetnie zrealizowany - obraz niewątpliwie miał znaczący wpływ na ugruntowanie tej wersji zdarzeń, która w świetle dokumentów okazała się nieprawdziwa. W latach sześćdziesiątych i następnych „Miś” był bardzo aktywnym narratorem, a w jego towarzystwie zaczęły, także w roli narratorek, występować dwie łączniczki „Pegaza”, które brały udział w akcji jako sygnalistki - Maria Stypułkowska-Chojecka „Kama” i Elżbieta Dziębowska „Dewajtis” oraz szef wywiadu kompanii - Aleksander Kunicki „Rayski”. A zatem, jeżeli pominąć „Rayskiego”, który udziału w akcji nie brał i w swoich wypowiedziach powtarzał błędy pozostałych, czworo uczestników akcji wypowiadało się po wojnie na temat przebiegu zdarzeń z ranka 1 lutego 1944 r. i miało do tego absolutnie prawo, choć do opowiadania wszystkiego o akcji - już nie.

Łączniczki w chwili, gdy rozległy się pierwsze strzały, były zamknięte w bramie domu przy ul. Szopena. Słyszały odgłosy walki, ale jej nie widziały. „Miś” - najpierw skupiony na kluczowym dla powodzenia akcji odpowiednim manewrowaniu autem, po wykonaniu tego zadania wyskoczył z wozu, razem z „Kruszynką” dobił Kutscherę i rewidował jego trupa w poszukiwaniu dokumentów. Od walczących kolegów oddzielały ich złączone ze sobą dwa samochody, które osłaniały ich od ostrzału ze strony

\footnotetext{
6 Marek Dunin-Wąsowicz został aresztowany 13 IV 1944 r. (trzy dni po aresztowaniu „Misia”) i po śledztwie, tym samym transportem obaj zostali wywiezieni do KL Stutthof. Wspólne przeżycia niewątpliwie położyły fundament pod przyjacielskie relacje Dunina-Wąsowicza i Issajewicza w okresie powojennym. Teksty poświęcone akcji na Kutscherę ukazały się w 1957 r. w 9 i 10 numerze „Przygody” - dodatku do „Życia Warszawy”.
} 
komendantury, ale zasłaniały także widok ${ }^{7}$. Oczywiście z perspektywy planu akcji i jego wykonania nie miało znaczenia, że „Kruszynka” i „Miś” nie widzieli działań osłaniających ich kolegów. Taki był sens dzielenia uczestników akcji na „wykonawców” i „ubezpieczenie” - każdy uczestnik miał przydzielone swoje zadania i na ich wykonaniu się skupiał, jednak dla oceny tego, co mogli widzieć i o czym mogli później wiarygodnie opowiedzieć - ma to istotne znaczenie.

„Miś” w trakcie walki otrzymał postrzał w głowę. Krew zalewała mu oczy, powodując dezorientację ${ }^{8}$. Co oczywiste, obaj nie byli świadkami dramatu, jaki rozegrał się na moście Kierbedzia, gdzie doszło do walki „Juna” i "Sokoła” z niemieckimi żandarmami - żaden z nich nie mógł wiedzieć, z jakiego powodu "Juno" i "Sokół” wracali ostrzelanym samochodem na zachodni brzeg Wisły po odwiezieniu rannych „Lota” i „Cichego” do szpitala na Pradze. Ani „Miś”, ani „Kruszynka” nie wzięli udziału w przeprowadzonej kilka godzin później akcji zabrania rannych ze szpitala Przemienienia Pańskiego ${ }^{9}$.

Z tych czworga „Kruszynka” złożył relację najwcześniej i jednocześnie z powodu śmierci nie mógł w zmienionych warunkach politycznych po roku 1956 swojej opowieści snuć czy też korygować. Natomiast narracja „Misia” prowadzona była od połowy lat pięćdziesiątych do pierwszej dekady XXI w. Wskazywałem już w innym tekście na zauważalną w jego opowieściach skłonność do przesady, która ostatecznie przybrała formę absurdalną ${ }^{10}$.

7 „Przy samochodach, jak za barykadą, klękają nad ciałem Kutschery Kruszynka i Miś. Szybko rewidują jego kieszenie", zob. M. Dunin-Wąsowicz, Zamach na Kutscherę, Warszawa 1958, s. 42.

8 „...zostaje trafiony w głowę. Krew zalewa mu twarz. [...] Nic nie widzi, biegnie prosto przed siebie. Straciwszy orientację, pobiegłby może na niechybną śmierć w stronę Szucha...,, zob. ibidem.

9 W akcji tej wzięła udział „Kama” i na temat swojego w niej udziału złożyła relację, której treść nie wykracza poza opis tego, co sama mogła widzieć i w czym brała udział, zob. Archiwum Adama Borysa, „Kama” (Maria Stypułkowska-Chojecka), „Wspomnienie związane z odbiciem ze szpitala «Lota» i «Cichego»", [b.m. 1956 r.], mps. Egzemplarz, do którego się odwołuję, był przechowywany przez Adama Borysa w jego prywatnym archiwum, które zostało mi udostępnione przez prof. Huberta Borysa w styczniu 2017 r. Zbiór ten został $21 \mathrm{X}$ 2017 r. w Sopocie przekazany do zasobu Archiwum Akt Nowych (dalej: AAN), ale do chwili oddania tego tekstu do redakcji nie był wpisany do inwentarza. Inna część Archiwum Adama Borysa została do AAN przekazana kilkanaście lat temu, ale udostępniona została dopiero w 2017 r. W tekście z konieczności rozróżniam te zbiory, choć w zasadzie tworzą one całość.

10 W. Stopczyński, O „Raporcie Alego z akcji na Kutscherę” - odpowiedź na polemikę dr Marii Wiśniewskiej, „Przegląd Historyczno-Wojskowy” (dalej: PHW) 2012, nr 2 (240), s. 166-167. Kilka lat przed śmiercią Michał Issajewicz udzielił na potrzeby Archiwum Historii Mówionej Muzeum Powstania Warszawskiego wywiadu, w którym całą zasługę zabicia Kutschery przypisał sobie i łączniczkom. 
Żaden z czwórki relacjonistów nie zajmował w oddziale funkcji dowódczych. Zadaniem żadnej z tych osób nie było sporządzanie poakcyjnych raportów, których napisanie wymagało spojrzenia na przebieg zdarzeń w sposób całościowy.

A zatem - relacje uczestników wydarzeń z 1 lutego 1944 r. przybierały nieuprawnioną formę opowieści „o wszystkim”, a relacjoniści właściwie wchodzili w rolę przypisaną historykom, rozstrzygając o sprawach, o których wiedzieć nie mogli lub mogli mieć wiedzę $\mathrm{z}$ drugiej czy trzeciej ręki ${ }^{11}$.

\section{Narracje}

Zamysł całościowego i obiektywnego opisania historii batalionu „Parasol” (wcześniej - „Agat”, „Pegaz”) powstał zaraz po zakończeniu wojny. Z inicjatywy prof. Józefa Zawadzkiego, Bolesława Srockiego i Adama Borysa „Pługa” gromadzono dokumenty, spisywano relacje, które najpierw trafiały do Wandy Leopold - wdowy po poległym w powstaniu warszawskim na Starym Mieście dowódcy 1 kompanii „Parasola” Stanisławie Leopoldzie „Rafale”, która po przepisaniu rękopisów na maszynie przekazywała materiały Srockiemu, który na ich podstawie, ale także na podstawie własnej znajomości ludzi i zdarzeń, opracowywał je w porozumieniu z „Pługiem”, do którego ostatecznie relacje i dokumenty trafiały, tworząc zbiór, który Srocki nazwał "Archiwum «Parasola»". Zachowały się cztery teksty „pana Bolesława" napisane na podstawie tych materiałów ${ }^{12}$. Ten o Bronisławie Pietraszewiczu „Locie” zawierał pierwszy, zmierzający do obiektywizmu, opis akcji na Kutscherę. Plan wydania tych tekstów z oczywistych powodów nie mógł być zrealizowany w latach czterdziestych. Maszynopis Srockiego trafił do „Archiwum «Parasola»".

Swojej wiedzy, tekstów i być może materiałów użyczał Srocki Aleksandrowi Kamińskiemu, którego znał doskonale z okresu okupacji i powstania warszawskiego ${ }^{13}$. Autor słynnych Kamieni na szaniec już w 1946 r. miał przygotowaną

\footnotetext{
11 Zagadnienie to dobrze ilustrują słowa Feliksa Wojtulewicza „Bąka”, poprzedzające jego relację o udziale w akcji na Alfreda Milkego: „Choć mój udział w tej akcji był niewielki, mogę opisać prawie całą akcję, lecz z zaznaczeniem, że tam gdzie nie byłem osobiście, mogło się odbyć coś inaczej niż opiszę, ale tak przetrwało to w mojej pamięci i trudno powiedzieć, co wiem z odprawy odbytej po akcji, a co od kolegów z kilku rozmów po akcji”, zob. Ośrodek „Karta” (dalej: OK), Archiwum „Parasola”, sygn. AW V/2.13, Feliks Wojtulewicz „Bąk”, „Akcja na Szucha (Milke)”, b.m. maj 1957 r., s. 1, mps, [Brak paginacji teczek archiwalnych, ale występuje paginacja wewnętrzna relacji, w związku z czym podana na końcu cytowania paginacja odnosi się do paginacji relacji. W kolejnych przypadkach odwoływania się do archiwaliów z tego zbioru powyższa praktyka będzie stosowana].

12 Wszystkie teksty wspomnieniowe Srockiego zob. W. Stopczyński, W kręgu..., s. 343-397.

13 Więcej na temat relacji Srockiego z Kamińskim zob. ibidem, s. 34 i n.
} 
pierwszą część kontynuacji swojej okupacyjnej książki, która miała przedstawiać walkę jej bohaterów w dywersji i dalej w otwartej walce z wrogiem. W części tej znalazł się także opis akcji na Kutscherę. Ale i książka Kamińskiego z tych samych powodów, co teksty Srockiego, nie mogła zostać dokończona i wydana w latach czterdziestych. Została opublikowana dopiero (albo - już) w 1957 r., a w posłowiu do pierwszego wydania autor wskazał na kluczowy udział Srockiego w przygotowaniu tych partii tekstu, które odnosiły się do akcji „Parasola” ${ }^{\text {. }}$. Próby obiektywnego opowiedzenia historii akcji na Kutscherę spełzły na niczym i najważniejszym w okresie tużpowojennym tekstem o jej przebiegu pozostała relacja „Kruszynki” ${ }^{15}$.

W 1956 r. środowisko żołnierzy „Parasola” powołało do życia Zespół Redakcyjny Kroniki „Parasola”, którego zadaniem było przygotowanie opracowania historycznego o dziejach oddziału. Podjęto także ponownie wysiłek gromadzenia dokumentów i relacji, które dołączono do tych spisywanych w latach czterdziestych. Przedsięwzięcie realizowane było pod auspicjami Zakładu Historii Najnowszej Polskiej Akademii Nauk oraz Biura Historycznego MON (później przekształconego w Wojskowy Instytut Historyczny [WIH]). W skład Zespołu Redakcyjnego weszli wtedy: Hanna Brudzyńska, Maria Dylawerska, Zbigniew Gąsior i Stanisław Jastrzębski, którzy działali „pod ogólnym kierownictwem ob[ywatela] Borysa $\mathrm{A}[$ dama]"16. Efektem pracy zespołu było trzyczęściowe opracowanie pt. „Kronika batalionu «Parasol»”, w którym opisano historię oddziału do wybuchu powstania warszawskiego ${ }^{17}$. I znowu - w miarę sprzyjająca koniunktura polityczna skończyła się, a przygotowany maszynopis ani wtedy, 14 A. Kamiński, Posłowie do I wydania [w:] idem, Zośka” i „Parasol”. Opowieść o niektórych
ludziach i niektórych akcjach dwóch batalionów harcerskich, Warszawa 2009, s. 571.

15 Tekst Srockiego po raz pierwszy opublikowano w 1956 r.: B. Srocki, Bronisław Pietraszewicz - organizator zamachu na Kutscherę, „Za Wolność i Lud” 1956, nr 8, s. 9-11.

16 Tak skład pierwszego Zespołu Redakcyjnego przedstawił Adam Borys podczas protokołowanego zebrania 20 XII 1959 r., na którym podsumowano i zakończono pracę zespołu. Oryginał protokołu z podpisami był w posiadaniu Adama Borysa. Odwołuję się do tego egzemplarza udostępnionego mi przez prof. Huberta Borysa. Archiwum Adama Borysa, Protokół z zebrania b. żołnierzy i rodzin b. baonu „Parasol” w dniu 20 grudnia 1959 zwołanego dla podjęcia decyzji w sprawie sprzedaży rękopisu kroniki i materiałów źródłowych Wojskowemu Instytutowi Historycznemu, b.m. 20 XII 1959 r., s. 1, mps, [Brak paginacji teczek archiwalnych, ale występuje paginacja wewnętrzna relacji i dokumentów, w związku z czym podana na końcu cytowania paginacja odnosi się do paginacji relacji lub dokumentu. W kolejnych przypadkach odwoływania się do archiwaliów z tego zbioru powyższa praktyka będzie stosowana]. Do wymienionych członków Zespołu Redakcyjnego dodać należy także Elżbietę Dziębowską i Danutę Kaczyńską, zob. ibidem, s. 2.

17 AAN, Instytut Historyczny PAN, sygn. A291-65, Zespół Redakcyjny Kroniki „Parasola”, Kronika batalionu „Parasol”, b.m., b.d., mps. Egzemplarz „Kroniki...” znalazł się także w posiadaniu Adama Borysa. 
ani później nie został wydany drukiem ${ }^{18}$. Fragmenty „Kroniki...”, będące opracowaniem poszczególnych akcji, ukazywały się najpierw w „Nowej Kulturze”, a następnie w wydawanym przez WIH „Wojskowym Przeglądzie Historycznym” w latach 1959-1963. W 1959 r. ukazał się tekst poświęcony akcji na Kutscherę ${ }^{19}$.

Podczas spotkania założycielskiego Komitetu Organizacyjnego Kroniki ustalono, że żołnierze i członkowie rodzin poległych będą spisywać relacje bezinteresownie i „do czasu opublikowania kroniki wstrzymają się od wydawania wspomnień" ${ }^{20}$. Warto dlatego odnotować, że „wspomnieniowa” i „konsultacyjna” aktywność Michała Issajewicza „Misia” w tym samym czasie wyraźnie stała w opozycji do wysiłku podejmowanego przez środowisko „Parasola”, pracujące pod „ogólnym kierownictwem” swego okupacyjnego dowódcy. Adam Borys zresztą reagował na tę aktywność. W 1957 r. na łamach „Nowej Kultury” Marek Dunin-Wąsowicz polemizował z "grupą «Parasol»" w sprawie „monopolu na badania i opisywanie poszczególnych wydarzeń $\mathrm{z}$ historii naszej walki o niepodległość" ${ }^{21}$. W krótkim tekście padły bardzo mocne słowa, a także oskarżenia o „zastraszanie stosowane przez «kronikarzy» wobec swoich kolegów - b. członków «Parasola» - m.in. bojkotu Michała Issajewicza"22. Nie próbując wyjaśniać źródła tego konfliktu, którego wyraźnym znakiem jest tekst Dunina-Wąsowicza, zacytujmy z niego fragment ważny dla prowadzonych tu rozważań: „Przed kilku miesiącami zwróciłem się do swego osobistego przyjaciela jeszcze z okresu spędzonego wspólnie w obozie koncentracyjnym Michała Issajewicza z propozycją spisania i opracowania jego interesujących osobistych wspomnień z czasu wojny i okupacji hitlerowskiej. Michał Issajewicz zgodził się i autoryzowane wspomnienia drukowane były w kilkunastu odcinkach $\mathrm{w}$ piśmie dla młodzieży «Przygoda». Wśród nich było także kilka poświęconych udziałowi Issajewicza w akcjach «Parasola» - m.in. w zamachu na Kutscherę, którego jest on jedynym żyjącym bezpośrednim uczestnikiem (żyją także

18 Wyrażono to oględnie w cytowanym wyżej protokole: „Wg opinii Wojskowego Instytutu Historycznego brak realnych warunków do wydania kroniki”. Archiwum Adama Borysa, Protokół z zebrania b. żołnierzy i rodzin b. baonu „Parasol” w dniu 20 grudnia 1959 zwołanego dla podjęcia decyzji w sprawie sprzedaży rękopisu kroniki i materiałów źródłowych Wojskowemu Instytutowi Historycznemu, b.m. 20 XII 1959 r., s. 3, mps.

19 M. Dylawerska et al., Akcja na..., s. 84-121.

20 Archiwum Adama Borysa, Protokół z zebrania b. żołnierzy i rodzin b. baonu „Parasol” w dniu 20 grudnia 1959 zwołanego dla podjęcia decyzji w sprawie sprzedaży rękopisu kroniki i materiałów źródłowych Wojskowemu Instytutowi Historycznemu, b.m. 20 XII 1959 r., s. 1 , mps.

21 M. Dunin-Wąsowicz, Polemika z grupa „Parasol”, „Nowa Kultura” 1957, nr 24, s. 7.

22 Ibidem. W żadnym przeglądanym przeze mnie zbiorze relacji $\mathrm{z}$ lat pięćdziesiątych nie znalazłem jakiegokolwiek maszynopisu z relacją Michała Issajewicza. 
i łączniczki). Wówczas zetknąłem się z p. Adamem Borysem reprezentującym grupę b. członków «Parasola», którzy zbierali materiały do własnej «kroniki». Wystąpił on z protestem przeciwko drukowanym wspomnieniom, uważając, że dopóki nie ukaże się kronika, nikt nie powinien pisać o «Parasolu». Nie miał on jednak żadnych zastrzeżeń co do prawdziwości podawanych przeze mnie faktów"23.

Na zebraniu w grudniu 1959 r., z którego protokół był tu cytowany, zdecydowano o sprzedaży maszynopisu „Kroniki...” i zebranych materiałów Wojskowemu Instytutowi Historycznemu. Na przełomie lat sześćdziesiątych i siedemdziesiątych do pracy nad przygotowaniem historii „Parasola” przystąpił inny były żołnierz batalionu - Piotr Stachiewicz. 13 kwietnia 1972 r. Stachiewicz stanął na czele powołanej przy Zarządzie Okręgu Warszawskiego Związku Bojowników o Wolność i Demokrację Komisji Historycznej Klubu Środowiskowego byłych żołnierzy batalionu „Parasol”24. W wyłącznych kompetencjach Komisji było rozstrzyganie wszelkich kwestii związanych $\mathrm{z}$ „opiniowaniem materiału wspomnieniowego", historią oddziału, jej publikowaniem we fragmentach lub w całości „i ich historyczne uściślenia”25. Adam Borys, krytyczny wobec koncesjonowanych przez władze organizacji kombatanckich, nie znalazł się oficjalnie w składzie komisji, ale pisząc „Przedmowę” do monografii autorstwa Stachiewicza, dał swoiste imprimatur książce, której oficjalna prezentacja odbyła się z jego udziałem 29 listopada $1981 \mathrm{r}^{26}$

Zanim do tego doszło, Stachiewicz publikował ekstrakty przygotowanych fragmentów książki w „Więzi”. Tam też opublikowano tekst poświęcony akcji na Kutscherę, który - o czym niżej - w jednym istotnym szczególe różnił się od wersji przedstawionej w monografii ${ }^{27}$. Dla dalszych rozważań i wniosków ważne jest zaakcentowanie, że „Parasol” Stachiewicza uzyskał

23 Ibidem. Nazwanie Adama Borysa „reprezentującym grupę b. członków «Parasola» bez podania, że był dowódcą oddziału, skłoniło redakcję „Nowej Kultury” do umieszczenia stosownych objaśnień pod tekstem.

24 W skład komisji weszli także: Barbara Hellwigowa, Zofia Łazorowa, Zbigniew Storożyński, Rajmund Caban, Bogdan Woźniak. Archiwum Adama Borysa, Jerzy Dargiel, Projekt komunikatu przewodniczącego Środowiska b. żołnierzy batalionu „Parasol” przy ZOW ZBoWiD, Warszawa 1972, mps.

25 Ibidem.

26 P. Stachiewicz, „Parasol”. Dzieje oddziału do zadań specjalnych Kierownictwa Dywersji Komendy Głównej Armii Krajowej, Warszawa 1981.

27 P. Stachiewicz, Akcja „Kutschera”, „Więź” 1975, nr 7-8, s. 114-135. Warto odnotować, że przygotowywano wtedy druk osobnej publikacji Stachiewicza o akcji na Kutscherę, który zrealizowany został dopiero w 1982 r. Zob. AAN, Akta Piotra Stachiewicza, sygn. 26, M. Stysiak, „Recenzja pracy Piotra Stachiewicza pt. «Akcja Kutschera», 5 X 1976 r., mps; P. Stachiewicz, Akcja „Kutschera”, Warszawa 1982. 
nie tylko „autoryzację” dowódcy batalionu, ale autor otrzymał także od Adama Borysa materiały archiwalne oraz - rzecz niewidziana we wcześniejszych opracowaniach - powołał się w interesującym nas zakresie akcji na Kutscherę - na jego relację. O trudnościach w uzyskaniu jakiejkolwiek autoryzowanej wypowiedzi „Dyrektora” pisała w 1982 r. w liście do Tomasza Strzembosza Maria Wiśniewska - członkini Zespołu Redakcyjnego „Kroniki «Parasola»": „Można powiedzieć, że jego [Adama Borysa] autorytet nie zmaterializował się $\mathrm{w}$ formie żadnej relacji, czy napisanych i autoryzowanych uwag do kroniki, jakie np. dał nam pułk. Kirchmajer [sic!]. Pomimo, że Kronika już była prawie napisana, usiłowałam coś jeszcze z Borysa wydusić. Były to żałosne 3 kartki mojego maszynopisu, nie autoryzowane przez niego, które zapisałam pod numerem 307 naszego zbioru relacji, opatrując tytułem «O Jeremim i interwencjach harcerskich». Materiał absolutnie chaotyczny. Nasz dowódca, tak samo jak i «Radosław» reprezentował pogląd, że nie czas, aby wyższy szczebel dowódców AK składał relacje. Jego oficjalne oświadczenia ograniczały się do tych samych ogólników, które wypowiada i dzisiaj i które każdy mógł usłyszeć, jeżeli brał udział w uroczystościach związanych $\mathrm{z}$ wydaniem opracowania «Parasol» Piotra Stachiewicza"28.

Z zapisów bibliograficznych w książce Stachiewicza wynikałoby, że autorowi udało się przełamać ten opór dowódcy do składania pisemnych relacji. I rzeczywiście - po pierwszym wydaniu „Parasola” Adam Borys przesłał Stachiewiczowi napisaną odręcznie relację odnoszącą się do fragmentu książki poświęconej osobie dowódcy, czyli jego samego ${ }^{29}$. Innych - autoryzowanych relacji dowódcy „Parasola” w „Aktach Piotra Stachiewicza” nie znalazłem. Nie musi to jednak oznaczać, że „Dyrektor” nie składał autorowi „Parasola” relacji ustnych. Z rozmów z nim Stachiewicz mógł sporząazać notatki - lub tego oczywiście nie robić. Zachowała się taka notatka, której treść może być przypisana Adamowi Borysowi, choć niewątpliwie nie została sporządzona jego ręką. W nagłówku ma „Doc. Dr A. Borys” i w punktach zawiera oceny ogólne i nieco bardziej szczegółowe książki, ale żadnych uwag dotyczących rozdziału o akcji na Kutscherę $e^{30}$ W istnienie relacji

\footnotetext{
28 AAN, Akta Adama Borysa, sygn. 1, List Marii Wiśniewskiej do Tomasza Strzembosza w sprawie książki Piotra Stachiewicza „Parasol”, b.m. 7 II 1982 r., s. 3, mps [Brak paginacji teczek archiwalnych, ale występuje paginacja wewnętrzna relacji i dokumentów, w związku z czym podana na końcu cytowania paginacja odnosi się do paginacji relacji lub dokumentu. W kolejnych przypadkach odwoływania się do archiwaliów z tego zbioru powyższa praktyka będzie stosowana].

29 AAN, Akta Piotra Stachiewicza, sygn. 41, List Adama Borysa do Piotra Stachiewicza w sprawie poprawek do Rozdziału 3 - „Dowódca oddziału”, b.m. 14 VII 1982 r., b.p., rkps.

30 AAN, Akta Piotra Stachiewicza, sygn. 47, Notatka Doc. Dr[.] A[dama]. Borys[a], b.m., b.d., b.p., rkps.
} 
„Dyrektora” (i „Radosława”), ale o akcji na Stamma, powątpiewała Maria Wiśniewska w liście do Tomasza Strzembosza, słusznie zauważając, że „jeżeli rzeczywiście uznaje się [Stachiewicz] za historyka, powinien ją [relację] opublikować, jeżeli nie wcześniej, to przynajmniej w aneksach lub podać ważne powody, dlaczego jej nie publikuje" ${ }^{31}$. Niezależnie od tego, czy relacja Borysa, na którą powołał się Stachiewicz w rozdziale poświęconym akcji na Kutscherę, istnieje - czy to w formie podpisanej przez „Dyrektora”, czy $\mathrm{w}$ formie notatki samego Stachiewicza - nie powinna być sprzeczna $\mathrm{z}$ tym, co autor „Parasola” napisał w odsyłaczu.

Zapewne aprobatywny stosunek „Dyrektora” do książki wpłynął na stłumienie pierwszych i następnych głosów krytycznych wobec książki Stachiewicza i wobec samego autora oraz uznanie jej za kanoniczną wersję historii batalionu „Parasol” ${ }^{32}$. Z biegiem czasu, mimo wciąż pojawiających się krytycznych recenzji ${ }^{33}$, ranga książki rosła, jednocześnie petryfikując

31 AAN, Akta Adama Borysa, sygn. 1, List Marii Wiśniewskiej do Tomasza Strzembosza w sprawie książki Piotra Stachiewicza „Parasol”, b.m. 7 II 1982 r., s. 4, mps. Uwaga Wiśniewskiej odnosi się do przypisu dziewiątego na stronie $17 \mathrm{w}$ pierwszym wydaniu, gdzie wyraźnie Stachiewicz pisze o „relacji płka «Radosława», a także kpt. «Pługa»". Akcja na Stamma została przeprowadzona 6 V 1944 r. w al. Szucha i zakończyła się krwawą klęską. Wykonawcy, wyposażeni w źle przygotowane dokumenty, poza jednym - nieznający języka niemieckiego, nawet nie dotarli do klatki schodowej prowadzącej do mieszkania Stamma. Zginęło ośmiu uczestników, w tym dowódca, który przed akcją, w imieniu żołnierzy oddziału wykonawczego, zgłaszał Adamowi Borysowi wątpliwości co do szans skutecznego wykonania źle przygotowanego planu. Rozkaz wykonania jednak został przez „Pługa” wydany. P. Stachiewicz, „Parasol”..., s. 366-367.

32 Bardzo krytycznie wobec książki Stachiewicza i osoby autora wypowiedziała się niedługo po premierze książki m.in. Maria Wiśniewska z Zespołu Redakcyjnego Kroniki „Parasola”, którego praca została w książce zdeprecjonowana, zob. P. Stachiewicz, „Parasol”..., s. 11; AAN, Akta Adama Borysa, sygn. 1, List Marii Wiśniewskiej do Tomasza Strzembosza w sprawie książki Piotra Stachiewicza „Parasol”, b.m. 7 II 1982 r., mps. Wyrażone w liście opinie zostały złagodzone w opublikowanej przez Wiśniewską recenzji: M. Wiśniewska, „Parasol” po czterdziestu latach, „Przegląd Powszechny” 1982, nr 1/2, s. 128-138. Wiśniewska bardzo krytycznie odniosła się także do samej, w jej ocenie wystawnej i przez to nietaktownej w ówczesnej sytuacji (na kilkanaście dni przed wprowadzeniem stanu wojennego), imprezy promującej książkę. W zakończeniu rozesłanego do redakcji „Tygodnika Powszechnego" i tygodników „Solidarność” oraz „Polityka” listu wskazała, że o takiej, a nie innej oprawie uroczystości zdecydował „głos dowódcy”, zob. AAN, Akta Piotra Stachiewicza, sygn. 26, List otwarty Marii Wiśniewskiej dedykowany „Marysi” i „Oli” - byłym żołnierzom batalionu „Parasol” Armii Krajowej, Warszawa 4 XII 1982 r., mps. Oczywiście wydanie tak długo oczekiwanej książki spowodowało bardzo wiele aprobatywnych głosów.

33 Chyba najmocniejszym głosem krytycznym i jednocześnie bardzo merytorycznym była kilkudziesięciostronicowa recenzja Andrzeja Chmielarza napisana po drugim wydaniu książki, zob. AAN, Akta Piotra Stachiewicza, sygn. 25, Andrzej Chmielarz, „Recenzja pracy Piotra Stachiewicza «Parasol. Dzieje oddziału do zadań specjalnych Kierownictwa Dywersji Komendy Głównej Armii Krajowej». Wydanie II przejrzane i uzupełnione, IW PAX, Warszawa 1984", Warszawa 1 XII 1986 r., mps. 
przedstawione fakty i ich interpretacje. Jak bardzo, pokazuje opinia Marii Stypułkowskiej-Chojeckiej przedstawiona w liście do mnie po poinformowaniu jej o odnalezieniu raportu „Alego” z akcji na Kutscherę: „wszystko, co można wiedzieć o oddziale do zadań specjalnych Komendy Głównej Armii Krajowej tj. o oddziale noszącym kolejne kryptonimy «Agat», «Pegaz», «Parasol» zawarto w publikacji p[od] tytułem Parasol Piotra Stachiewicza. Autor długo przygotowywał tę książkę, przeprowadzając badania dokumentów, liczne rozmowy i dyskusje z uczestnikami wydarzeń, a w końcu uzyskał aprobatę tekstu przez dowódcę oddziału Adama Borysa (ps. "Pług», «Dryl», «Dyrektor»). Publikację akceptował także kierownik komórki wywiadowczej Aleksander Kunicki (ps. «Rayski», «Marian»), z tekstem zapoznawali się także żyjący wtedy uczestnicy wydarzeń, żołnierze i łączniczki tego oddziału”34. Niewątpliwie do dziś książka „Parasol” Piotra Stachiewicza i zawarte w niej opracowanie akcji na Kutscherę mają rangę kanonicznych.

\section{Dokumenty}

Dzisiaj już wiemy, że po akcji na Kutscherę sporządzono trzy dokumenty. Chronologicznie pierwszym był wysłany drogą alarmową do dowódcy Kedywu płk. Augusta Emila Fieldorfa „Nila” meldunek dowódcy „Pegaza”, w którym kpt. Adam Borys „Pług” „informował płk. «Nila» o konieczności podjęcia decyzji przeprowadzenia akcji ewakuacji rannych ze szpitala, zawierał prośbę o uzupełnienie uzbrojenia oddziału, wreszcie pochwałę zespołu wykonawczego. W sumie dziewięć krótkich zdań” ${ }^{35}$. Wydaje się, że pierwszy raz w kontekście opisu akcji na Kutscherę dokument ten pojawił się dopiero w 1972 r. w tekście Piotra Stachiewicza opublikowanym w „Więzi”36. Fotokopię fragmentu meldunku zamieścił Stachiewicz w wydanej w 1981 r. książce ${ }^{37}$. Sporządzenie tego dokumentu i wysłanie go w trybie alarmowym wymuszone było zaistniałą po akcji sytuacją. Do 1993 r. był to jedyny znany i uznany za oryginalny dokument wytworzony w oddziale wykonującym akcję. Wtedy właśnie dr Henryk Piskunowicz opublikował w „Wojskowym Przeglądzie Historycznym” treść odnalezionego przez siebie w Archiwum Akt Nowych raportu z akcji na Kutscherę napisanego przez zastępcę dowódcy akcji - Stanisława Huskowskiego „Alego" ${ }^{3}$. Odkrycie dr. Piskunowicza przeszło bez echa. Nie zareagowało

34 List Marii Stypułkowskiej-Chojeckiej do Waldemara Stopczyńskiego, Warszawa 6 III 2008 r., mps [list w posiadaniu Waldemara Stopczyńskiego].

35 W. Stopczyński, $O$ „Raporcie Alego..., s. 163.

36 P. Stachiewicz, Akcja..., „Więź”, s. 114.

37 P. Stachiewicz, „Parasol”..., s. 342.

38 H. Piskunowicz, Zamach na Kutscherę w świetle raportu Stanisława Huskowskiego („Ali”), WPH 1993, nr 2, s. 190-195. 
ani środowisko kombatantów - byłych żołnierzy „Parasola”, ani historyków. Albo przeoczono ważki temat, albo nabrano wody w usta. Sprawa ożyła dopiero w 2008 r. w związku z realizowanym przeze mnie projektem edukacyjnym, ale jednocześnie pojawienie się w naukowym obiegu nowego dokumentu spotkało się z gwałtownym wyparciem Marii Stypułkowskiej-Chojeckiej „Kamy” jedynej żyjącej wtedy uczestniczki akcji, która zabierała w jej sprawie głos oraz deprecjonującym raport „Alego” jako wiarygodne źródło informacji stanowiskiem historyków z Instytutu Pamięci Narodowej - dr. Tomasza Łabuszewskiego i dr. Kazimierza Krajewskiego ${ }^{39}$. Publikowane przeze mnie teksty zmierzały do wykazania, że wbrew przyjętemu na zasadzie aksjomatu przekonaniu, iż raport $\mathrm{z}$ akcji na Kutscherę nigdy nie powstał, raport musiał zostać sporządzony i musiał go napisać Stanisław Huskowski „Ali”. Dokument w końcu musiał przejść przez ręce dowódcy „Pegaza” kpt. Adama Borysa, który jego treść zaakceptował i przesłał do sztabu Kedywu Komendy Głównej Armii Krajowej (KG AK). Dzisiaj te wywody wydają się niepotrzebne. W 2014 r. w reportażu Mirosława Maciorowskiego Teczka „Alego” w dodatku „Ale Historia” do "Gazety Wyborczej” wicedyrektor Archiwum Akt Nowych Mariusz Olczak stwierdził, że w istniejącej dokumentacji (czyli: meldunek „Pługa” do „Nila” z 2 lutego i raport „Alego”) brakuje jeszcze jednego elementu: „Niejasne jest tylko to, jak ten dokument trafił do archiwum «Kedywu», bo nie ma na nim stosownej sygnatury. Nie wiadomo też, jak został potraktowany - powinien zachować się jakiś komentarz, notatka kogoś z dowództwa. Nic takiego nie ma, a przecież zamach na Kutscherę to była niezwykła akcja, w której życie straciło czterech żołnierzy" 40 .

Słowa pracownika AAN nie do końca odpowiadają prawdzie. W praktyce dekretacje dowódcy „Pegaza” nanoszone były na egzemplarzu raportu z akcji przesyłanym do dowództwa Kedywu. Tak jest na przykład w przypadku raportu "Jeremiego" z akcji na Franza Bürkla: na ostatniej stronie pod podpisem "Jeremiego" znajduje się adnotacja dowódcy oddziału: „P. «Nil». Przesyłam raport dcy «Jeremiego» z akcji przeciwko p. B. «Bryl».

39 W. Stopczyński, Teczka petna granatów, „Kombatant” 2009, nr 3, s. 3-9; M. Wiśniewska, Na marginesie artykułu Waldemara Stopczyńskiego „Teczka petna granatów”, PHW 2011, nr 4 (237), s. 221-224; W. Stopczyński, O „Raporcie Alego..., s. 161-172; W. Stopczyński, „Zamach na Kutscherę", czyli IPN-u kłopot $z$ raportem „Alego”, https://histmag.org/Zamach-naKutschere-czyli-IPN-u-klopot-Z-raportem-Alego-16326/1 (dostęp 29 VII 2018).

40 M. Maciorowski, Teczka „Alego”, „Ale Historia” dodatek do „Gazety Wyborczej” 2014, nr 5, s. 13. Autor reportażu uzyskał także komentarz Marii Stypułkowskiej-Chojeckiej „Kamy”, która do końca pozostała „sceptyczna”, przywołując rzekome zasady, które miały obowiązywać podczas planowania akcji: „Jeśli «Ali» przed akcją dostał teczkę z granatami, to raczej nie mógł dostać pistoletów - albo jedno, albo drugie, takie były zasady. Po prostu zdarzyła mu się przykra przygoda spowodowana złośliwością rzeczy martwych. Nikt nie miał o to do niego pretensji - przekonuje", zob. ibidem. 
I tyle - żadnego komentarza czy notatki. Wydaje się, że w 2014 r. Olczak antycypował odkrycie, którego dokonał w zasobach AAN. Dwa lata po reportażu w „Ale Historia” wicedyrektor AAN opublikował zdjęcie fragmentu i treść całego dokumentu, który nazwał „,raportem Borysa”, choć bardziej adekwatną nazwą jest "pismo przewodnie" ${ }^{41}$. Sporządzony odręcznie tą samą ręką, która pisała meldunek z 2 lutego, był datowany na 2 marca 1944 r. - tak samo jak raport "Alego" ${ }^{42}$ i skierowany do szefa sztabu Kedywu KG AK mjr. Wacława Janaszka „Bolka”43.

Odkrycie tego dokumentu - pisma przewodniego dowódcy Adama Borysa „Pługa” dołączonego do raportu „Alego” z akcji na Kutscherę - moim zdaniem rozstrzyga kwestię wiarygodności raportu napisanego przez Stanisława Huskowskiego, gdyż dowódca „Pegaza” niedługo po akcji nie podważył opisanego w raporcie przebiegu zdarzeń. Oczywiście nie da się wykluczyć, że pojawią się jeszcze inne archiwalia w sprawie akcji „Kutschera”, ale te, które dzisiaj mamy, sprawiają wrażenie kompletu dokumentów poakcyjnych wytworzonych w oddziale „Pegaz”. To są te "relacje urzędowe”, o których na przełomie 1945 i 1946 r. pisał Bolesław Srocki, że pozwolą ustalić „kto brał udział w zamachu, kto ocalał czy zginął, ile było samochodów i jak rozstawione".

${ }^{41}$ M. Olczak, Akcja na Kutscherę - nowe ustalenia, „Biuletyn Informacyjny” [miesięcznik Światowego Związku Żołnierzy Armii Krajowej] 2016, nr 2, s. 77-81.

42 Olczak stwierdził, że Adam Borys osobiście zapisywał datę w dokumencie sporządzonym przez „Alego”, zob. ibidem, s. 78. Jest to wątpliwe. Moją uwagę na fakt, że ani pismo w meldunku z 2 lutego, ani to z pisma przewodniego nie jest pismem Adama Borysa, zwrócił uwagę jego syn - prof. Hubert Borys. Oczywiście kwestię mogłaby definitywnie rozstrzygnąć specjalistyczna ekspertyza, ale różnice pisma w interesujących nas dokumentach i w próbkach pisma Adama Borysa są zauważalne okiem laika. Zwraca uwagę odmienny zapis datowania miesięcy w dokumentach: w meldunku do "Nila” luty zapisany jest cyfrą arabską, w raporcie „Alego" marzec zapisano cyfrą rzymską, a na piśmie przewodnim znowu widzimy zapis arabski. Dlaczego nie pisząc, ale dyktując treść pism do dowództwa Kedywu KG AK, miałby Borys osobiście zapisywać tylko datę? Dlaczego miałby sam nanosić ją na przekazanym przez „Alego” raporcie? Sprawa ta wydaje się mieć drugorzędne znaczenie, choć Olczak wyciąga z tego wniosek istotny - być może błędny - że pismo przewodnie zostało sporządzone 2 III $1944 \mathrm{r}$.

43 W interesującym nas tutaj okresie - między 2 II 1944 r. (data sporządzenia meldunku do „Nila”) a 2 III 1944 r. (datowanie raportu "Alego” i pisma przewodniego Adama Borysa) - dokonała się zmiana na stanowisku dowódcy Kedywu KG AK - płk. Fieldorfa „Nila” zastąpił ppłk Jan Mazurkiewicz „Sęp”. W AAN zachował się raport szefa wywiadu „Pegaza” Aleksandra Kunickiego „Rayskiego” z 7 II 1944 r. niemający związku z akcją na Kutscherę i skierowany przez nadawcę bezpośrednio do płk. „Nila”. Na dokumencie ołówkiem skreślono pseudonim „Nil” i zapisano „BBolek» dla «Sępa»”, zob. AAN, Zespół Akt Konspiracyjnych, sygn. VIII/22, Raport „Rayskiego” z 7 II 1944, rkps. 


\section{Protokół rozbieżności}

Pojawienie się $\mathrm{w}$ naukowym obiegu raportu z akcji na Kutscherę wymusiło pytania o wiarygodność relacji jej uczestników oraz wiarygodność i rzetelność opracowań historycznych. Różnice między spetryfikowaną narracją a - najwcześniejszym ze wszystkich(!) - zapisem przebiegu zdarzeń w dokumencie sporządzonym po akcji przez Stanisława Huskowskiego „Alego” i przesłanym przez dowódcę „Pegaza” Adama Borysa „Pługa” do sztabu Kedywu KG AK - dotyczą szczegółów, ale szczegółów o pierwszorzędnym znaczeniu. Poza tym różnice te mają tę naturę, że są nieusuwalne, bo albo ktoś miał broń, albo jej nie miał; albo umknął z pola walki, albo na nim pozostał - pierwsze to tchórzostwo, drugie - determinacja i wola wykonania rozkazu mimo niesprzyjających okoliczności. Albo ktoś zginął, bo nie wykonał rozkazu, albo poległ, bo go wykonał - pierwsze to głupia brawura i samowola, drugie - żołnierska dyscyplina. Wyliczmy dla porządku te rozbieżności, analizowane już w publikowanych tekstach ${ }^{44}$.

1) Wbrew relacjom i opracowaniom „Ali” otrzymał broń palną przed wyjściem na akcję - jeden pistolet parabellum miał, jak każdy członek zespołu ubezpieczającego, drugi otrzymał od „Juna”, gdy okazało się, że nie dostarczono pistoletu maszynowego.

2) Po niepowodzeniu z otwarciem teczki z granatami „Ali” nie oddala się pierwszy do samochodów przeznaczonych do odskoku, ale bierze udział w walce do końca.

3) "Sokół” i „Juno" zginęli w nurtach Wisły po skoku z mostu Kierbedzia nie dlatego, że zignorowali rozkaz „Lota” pozostawienia postrzelanego samochodu na Pradze, ale dlatego, że rozkaz wydany przez rannego dowódcę akcji odprowadzenia auta $\mathrm{z}$ bronią na lewobrzeżną stronę wykonali.

4) Stanisław Huskowski „Ali” został wyznaczony na zastępcę dowódcy akcji nie na odprawie przedakcyjnej 29 stycznia, ale 1 lutego w drodze z punktu zbiórki na miejsce akcji.

Odnotujmy, że żadna z tych rozbieżności nie występuje w opracowaniach Bolesława Srockiego i Aleksandra Kamińskiego - wydaje się, że obaj nie pisali tego, czego nie mogli wiedzieć. $Z$ wczesnej relacji Zdzisława Poradzkiego „Kruszynki” dowiadujemy się, że to on miał odebrać pół godziny przed akcją broń od łączniczki na rogu ul. Piusa XI i Mokotowskiej, ale wrócił po chwili „na melinę” z niczym ${ }^{45}$. Co do zachowania „Alego”, w jego opisie nie znajdziemy niczego godzącego w dobre imię zastępcy dowódcy

\footnotetext{
$44 \quad$ Zob. przyp. 39.
}

45 Z. Poradzki, Zamach na Kutscherę, „Rzeczpospolita”, 10 II 1947. „Kruszynka” odnotowuje, że „Ali” „zostaje grenadierem. Ładuje pełną teczkę filipinek”. Z jego opisu nie wynika 
akcji. „Kruszynka” stwierdza, że „Ali” „nie zorientowawszy się w sytuacji, nieopatrznie idzie w jego [rannego «Lota» biegnącego w stronę samochodów na ul. Szopena] ślady”46. Zespół Redakcyjny Kroniki „Parasola” w opublikowanym w WPH artykule wskazał, że „Ali” nie miał żadnej broni palnej. Jego zachowaniu podczas akcji poświęcono jedno zdanie, którego druga część stoi w sprzeczności z raportem z akcji: „Ali nie otworzył teczki z filipinkami i wycofał się do samochodu «Bruna»" ${ }^{47}$. Co do okoliczności śmierci "Sokoła” i „Juna” autorzy rozstrzygają jednoznacznie, że nie wykonali oni wyraźnego rozkazu dowódcy ${ }^{48}$. W sprzeczności z raportem stoi też informacja, że na zastępcę dowódcy akcji wyznaczył „Alego” „Lot” podczas odprawy 29 stycznia.

W pierwszych relacjach Michała Issajewicza „Misia” w opracowaniu Marka Dunina-Wąsowicza najistotniejszą rozbieżnością jest wskazanie na samowolę „Sokoła” i „Juna”, której konsekwencją była ich śmierć. O udziale w akcji "Alego" właściwie autor nie wspomina, odnotowując jedynie, że "Ali”, „którego zadaniem jest ubezpieczać samochody z rannymi”, wycofuje się - za rannymi „Cichym” i „Olbrzymkiem”"

Jednak „Misia” obciąża bardzo mocno to, co firmował własnym nazwiskiem i to, co mówił w latach późniejszych. Wspominałem wyżej, że w 1958 r. Michał Issajewicz konsultował od strony historycznej film Zamach Jerzego Passendorfera. W pierwszym tekście, który analizował raport „Alego” w kontekście spetryfikowanych narracji o akcji „Kutschera”, pisałem o krzywdzącym Stanisława Huskowskiego „Alego” obrazie, za którego nakreślenie większa odpowiedzialność ciąży na konsultancie historycznym niż na reżyserze ${ }^{50}$. Odsyłając Czytelnika do tego tekstu, odnotujmy tutaj jeden tylko epizod przedstawiony w filmie - ważny w kontekście ujawnionego przez Mariusza Olczaka dokumentu dołączonego do raportu $\mathrm{z}$ akcji. Scena rozgrywała się $\mathrm{w}$ aucie podczas odwrotu z akcji. Grany przez Tadeusza Łomnickiego „Marek”, którego pierwowzorem

wcale, że „Ali” nie miał przy sobie broni krótkiej. Oczywiście - nie ma w nim jasnej informacji, że ją miał.

46 Ibidem. Analizując przebieg zdarzeń, które następowały błyskawicznie i równocześnie, można uznać, że „Kruszynka” widział „Alego” biegnącego w stronę narożnika ul. Szopena i był przekonany, że ten biegnie do aut. Po chwili „Kruszynka” był już pochylony nad trupem Kutschery i osłonięty od strony komendantury autami i nie widział, że „Ali” zatrzymał się na rogu Alej i Szopena, ostrzeliwując się od strony placu Na Rozdrożu. „Kruszynka” w ogóle nie wspomina o tym, że "Ali” nie otworzył teczki z granatami.

47 M. Dylawerska et al., Akcja..., s. 97.

48 Ibidem, s. 99.

49 M. Dunin-Wąsowicz, Zamach..., s. 41. Można to zrozumieć w ten sposób, że „Ali” wykonuje powierzone mu zadanie.

50 W. Stopczyński, Jedna minuta i czterdzieści sekund, http://www.gfo.iq.pl/gag/images/stories/raport_alego/1.40sek.pdf (dostęp 16 VIII 2018). 
jest „Ali” - oddaje łączniczce teczkę z granatami, z której otwarciem nie poradził sobie w akcji. Mówi, że zamek się zaciął. Łączniczka odbiera teczkę i spokojnie, bez żadnego problemu otwiera ją. Sugestia, że zawinił człowiek, a nie złośliwość rzeczy martwych, jest wyraźna. Niespełna dziesięć lat później „Miš” nie pozostawił już niczego domysłom i interpretacjom. 9 stycznia 1967 r. w Polskim Radiu wyemitowano audycję-reportaż Krystyny Uzarek i Grażyny Wilkowskiej pt. Lekcja judo. W pierwszych minutach audycji Issajewicz mówi, że „tę teczkę [z granatami] bardzo lekko można było otworzyć... Czyli on [„Ali”] przechodził kryzys jakiś w tym momencie". Nieco wcześniej powiedział bez ogródek, że „Ali” „właśnie wtedy, w czasie tej akcji [na Kutscherę] się załamał”51. W mojej ocenie Michał Issajewicz „Miś” nie tyle ugruntował, co stworzył obraz rozedrganego emocjonalnie "Alego" - intelektualisty, który wpadł na pomysł, że weźmie udział w akcji i w tej akcji całkowicie zawiódł, co doprowadziło do jego psychicznego załamania. Tak, odwołując się do tej właśnie relacji „Misia”, zachowanie „Alego" przedstawił Piotr Stachiewicz w książce „Parasol”.

Poza tą jedną nieścisłością - „autoryzowana” przez Adama Borysa książka Stachiewicza zawierała już pełen zestaw „deformacji” i rozbieżności $\mathrm{w}$ zestawieniu $\mathrm{z}$ raportem $\mathrm{z}$ akcji, który - wiemy to już na pewno - przeszedł przecież przez ręce dowódcy „Pegaza”. A zatem wypunktujmy:

1) „Alego" na zastępcę wyznaczył „Lot” podczas odprawy odbytej 29 stycznia w obecności „Pługa” 53 .

2) Dla "Alego" zabrakło pistoletu maszynowego oraz broni krótkiej i „Ali” miał wyjść do walki uzbrojony jedynie w granaty zamknięte w teczce ${ }^{54}$.

3) „Ali” nie otworzył teczki i „załamany ruszył w kierunku samochodów przeznaczonych do odskoku. Dla niego był to koniec akcji i początek wielkiej, osobistej tragedii" ${ }^{55}$.

4) „Sokół” i „Juno” sami podjęli decyzję o powrocie ostrzelanym samochodem na lewy brzeg Wisły ${ }^{56}$.

51 http://www2.polskieradio.pl/wojna/posluchaj.aspx?sid=4 (dostęp 16 VIII 2018).

52 Właściwie Stachiewicz zrobił odnośnik do prasowej wersji reportażu, która ukazała się w 1970 r. w miesięczniku „Kontrasty” i była literalnym zapisem audycji radiowej, zob. P. Stachiewicz, „Parasol”..., s. 329. W innym miejscu, opisując perturbacje z rozdziałem broni przed akcją, autor „Parasola” napisał: „Zmiana pistoletu maszynowego na teczkę pełną granatów stała się początkiem tragicznego splotu wydarzeń, który w konsekwencji doprowadzi do załamania się "Alego»", zob. ibidem, s. 326.

53 Ibidem, s. 323-324.

54 Ibidem, s. 326.

55 Ibidem, s. 329.

56 Ibidem, s. 332. Stachiewicz nie pisze wprost o złamaniu rozkazu „Lota”, bo nie wspomina o wydaniu przez niego jakiegokolwiek polecenia. „Sokól” i „Juno” mieli polecenie, choć nie wiadomo, przez kogo przekazane, aby „zabrać samochód, na którym widniały ślady walki [...] i porzucić w najbliższym dogodnym miejscu”. Jednocześnie, snując w tym miejscu 
Do tego zestawu dodajmy jeszcze symptomatyczną zmianę w opisie wydarzeń z 1 lutego 1944 r., jakiej dokonał Stachiewicz w wydanej w 1981 r. monografii w stosunku do wersji opublikowanej w „Więzi”. Jeszcze w 1975 r. Stachiewicz nie miał wątpliwości co do aktywnego udziału "Alego” w akcji ewakuowania rannych „Lota” i „Cichego” ze szpitala Przemienienia Pańskiego, która odbyła się kilka godzin po wydarzeniach, jakie miały doprowadzić do rzekomego załamania Huskowskiego ${ }^{57}$. W „Parasolu” uznał, że składu oddziału wykonującego akcję szpitalną „nie można dostatecznie wiarygodnie ustalić" i w ten sposób zwolnił się z obowiązku napisania o udziale w niej „Alego" ${ }^{2}$. Stachiewicz niewątpliwie wiedział, bo wystarczająco dużo miał relacji, o udziale "Alego" w likwidowaniu skutków porannej akcji w Al. Ujazdowskich ${ }^{59}$. Wiedział, że to „Ali” (a nie na przykład „Kruszynka”) wydawał polecenia rodzicom zabitego w nurtach Wisły Kazimierza Sotta „Sokoła”, aby opuścili zagrożone dekonspiracją mieszkanie na Rynku Nowego Miasta, że popołudniu wynosił rannych ze szpitala na Pradze, że z 1 na 2 lutego wraz z Józefem Szczepańskim „Ziutkiem” stanowił zbrojną obstawę rannych umieszczonych na noc $\mathrm{w}$ klinice dr. Webera przy ul. Chmielnej ${ }^{60}$ i dopiero rankiem 2 lutego - po niemal 24 godzinach - kończy się dla niego akcja „Kutschera”. Zabieg Stachiewicza, który nazwałem - odwołując się do zabiegu fabularnego znanego $\mathrm{z}$ antycznego teatru - deus ex machina ${ }^{61}$, jest na swój sposób logiczny. Przecież tak aktywny i długi udział „Alego” $\mathrm{w}$ wydarzeniach stoi $\mathrm{w}$ jaskrawej sprzeczności z nakreślonym wizerunkiem

dywagacje o motywach, którymi kierowali się „Sokól” i „Juno”, być może autor zbliża się do wyjaśnienia sensu wydanego przez „Lota” rozkazu - pozostawienie auta w pobliżu szpitala dekonspirowało rannych.

57 P. Stachiewicz, Akcja..., s. 127.

58 P. Stachiewicz, „Parasol”..., s. 334.

59 W. Stopczyński, $O$ „Raporcie..., s. 169. Opisując akcję szpitalną, Stachiewicz cytuje m.in. relację jej uczestnika Eugeniusza Lubieńskiego „Pająka”. Nie podaje jednak tych jej części, które jednoznacznie mówią o udziale „Alego”. Trudno mówić tutaj o braniu pod uwagę pomyłki relacjonisty, który podaje taki szczegół, jak poczęstowanie „roztrzęsionego po porannej akcji” „Alego” papierosem „popularnym”, zob. Archiwum Adama Borysa, E. Lubieński „Pająk”, „Akcja odbicia ze szpitala Przemienienia Pańskiego D-cy akcji «Kutschera» - «Lota» i «Cichego»", b.m., b.d., s. 5, mps. Z kolei w swoich komentarzach do „Kroniki «Parasola»” „Pająk” napisał o składzie oddziału: „Nie ulega wątpliwości, że bezpośrednio brali udział w akcji następujący uczestnicy poza «Dyrektorem»: 1) «Jeremi», 2) «Kopeć», 3) «Orkan», 4) «Hipek», 5) «Cyklon», 6) «Zabawa», 7) «Bolec», 8) «Mrok», 9) «Pająk», 10) «Ali», 11) «Ziutek», 12) «Bartek» kierowca”, zob. AAN, Akta Piotra Stachiewicza, sygn. 44, E. Lubieński „Pająk”, Moje uwagi do „Kroniki”, b.m. 24 VI 1958 r., s. 3, mps.

60 Ta długa obecność „Alego” przy rannych może wyjaśniać, skąd podana przez niego w raporcie informacja o rozkazie odprowadzenia auta "Sokoła” wydanym przez „Lota”. To tylko przypuszczenie (i takim zapewne pozostanie) - otrzymał ją od rannego „Lota”.

61 W. Stopczyński, O „Raporcie..., s. 169. 
załamanego człowieka, dla którego akcja skończyła się po zajęciu miejsca w stojącym przy ul. Szopena samochodzie „Bruna”. Autor być może dążył do stworzenia narracji wiarygodnej od strony psychologicznej i dlatego przemilczał to, co mogło tę wiarygodność zakwestionować.

\section{Czego Adam Borys nie powiedział...}

Była tylko jedna osoba, która doskonale wiedziała, że nakreślony przede wszystkim przez Stachiewicza - ale także przez „Misia” czy Zespół Redakcyjny Kroniki „Parasola” - obraz przygotowań do likwidacji Kutschery, przebiegu samej akcji, udziału w niej i w wydarzeniach po niej następujących Stanisława Huskowskiego "Alego" jest nieprawdziwy. Był to kapitan Adam Borys „Pług” - organizator i dowódca kompanii „Agat”, „Pegaz” i później batalionu „Parasol”.

Starałem się wykazać wyżej, że dowódca „Parasola” nigdy nie stracił z oczu i nie wypuścił z rąk powojennej narracji o akcji na Kutscherę, że zdawał sobie sprawę, w jakim kierunku ta narracja zmierza. Autoryzował i oficjalnie promował wersję ostatnią, w której jest najwięcej odstępstw i zniekształceń w stosunku do raportu „Alego”, którego treści Adam Borys nie podważył ani na jotę w przesłanym do sztabu Kedywu KG AK piśmie przewodnim w lutym-marcu $1944 \mathrm{r}$.

Adam Borys nie powstrzymał Piotra Stachiewicza, gdy ten pisał: „W oddziale, wbrew przyjętemu zwyczajowi, nie analizowano na odprawie lub odprawach poakcyjnych przebiegu dokonanych działań. Nie było na to czasu, nie było z kim analizy tej prowadzić. Wnioski zrekapitulował jednak kpt. «Pług» i zostały one omówione na odprawach płka «Nila»". I nie powstrzymał go, gdy zapis ten opatrywał odnośnikiem kierującym do relacji... Adama Borysa ${ }^{62}$. A przecież stoi on w sprzeczności z akcentowanym we „Wstępie” do „Parasola” „szkoleniowym” aspektem przeprowadzanych akcji, w których ważny jest nie tylko osiągnięty efekt, ale także ,udział w analizowaniu przyczyn osiągniętego sukcesu lub popełnionych błędów zarówno w samej akcji, jak i w przygotowaniu specjalnej operacji bojowej”, a to po to, żeby „wyciągnąć maksimum efektów szkoleniowych" ${ }^{63}$. Zrezygnowano zatem $\mathrm{z}$ analizowania przyczyn osiągniętego wielkiego sukcesu i poniesionych strat własnych, które sięgały przecież niemal 50\% zespołu wykonującego akcję i po raz pierwszy były tak znaczne.

Dlaczego „Dyrektor” nie przeciął - choć mógł to zrobić w każdej chwili karkołomnych dywagacji i dlaczego dopuścił do manipulacji krzywdzących

62 P. Stachiewicz, „Parasol”..., s. 346. Relację Adama Borysa opatrzył Stachiewicz cyfrą „3”, co w książce „Parasol”... oznacza, że relacja została złożona na jego prośbę w latach 19761979, a zatem po publikacji tekstu Stachiewicza w „Więzi”, zob. ibidem, s. 17.

63 Ibidem, s. 16. 
pamięć o jego poległych podkomendnych, których sam wysłał do walki? Dlaczego przed wszystkimi, którzy pisali o akcji na Kutscherę, zataił fakt istnienia raportu $\mathrm{z}$ tej akcji?

\section{...I co powiedział}

To milczenie dowódcy jest zastanawiające, ale w jeszcze większe zdumienie wprawia zestawienie tego, co Adam Borys powiedział o akcji na Kutscherę, w tym o udziale w niej Stanisława Huskowskiego „Alego”. Bo Adam Borys o Stanisławie Huskowskim wypowiedział się co najmniej dwukrotnie. Obie wypowiedzi dzieli czterdzieści lat, w trakcie których dokonała się deformacja narracji historycznej.

Pierwsza wypowiedź to oczywiście pismo przewodnie dołączone do raportu „Alego", które w AAN odnalazł dwa lata temu Mariusz Olczak. Przytoczmy tutaj jego treść w całości:

„Przesyłam raport z-cy d-cy akcji na p[ana] K[utscherę].

Ocena: plan akcji opracował ś.p. «Lot» bardzo śmiało i dokładnie.

Stwierdzam następujące niedociągnięcia $\mathrm{w}$ wykonaniu:

1) «Ali», z-ca dowódcy nie wypróbował czy teczka, w której miał filipinki, otwiera się i przed akcją i [przez co] w konsekwencji, w czasie akcji nie wykonał swego zadania, które polegało na obrzuceniu budynku filipinkami.

2) «Ali», jako z-ca d-cy w momencie śmiertelnego zranienia ś.p. «Lota», nie zorientował się w sytuacji, i nie przejął w swoje ręce dowodzenia akcją.

3) mimo, że zauważył rannych w czasie odskoku samochodem, «Ali» nie próbuje utrzymać kontaktu z samochodem wiozącym rannych, zwłaszcza nie jedzie na punkt, na którym czekał lekarz na rannych.

ad. 1-3. Błędy popełnione przez «Alego» mogę wytłumaczyć tylko małym doświadczeniem bojowym.

4) ś.p. «Lot» zlekceważył sobie użycie łączniczek do podjęcia broni z samochodów jadących $\mathrm{z}$ akcji, wskutek czego utraciliśmy broń i przypuszczalnie 2 ludzi.

5) stwierdzam słabe przygotowanie szpitali na przyjęcie rannych oraz kardynalny błąd lekarza, który zawiózł rannych do szpitala obsadzonego przez G[estap]o i [Policję] P[olską].

6) Muszę podkreślić nadzwyczajną bojowość ludzi biorących udział $\mathrm{w}$ akcji, oraz fakt, że 3 ludzi śmiertelnie rannych ewakuuje się o własnych siłach do samochodów, oddalonych ok. $100 \mathrm{~m}$. od miejsca akcji.

$\ll \mathrm{B}[\mathrm{ryl}] »^{64}$.

W dokumencie, jak to już stwierdzałem, dowódca nie zakwestionował podanego przez „Alego” przebiegu zdarzeń. Wyraził jednak swoje krytyczne

64 M. Olczak, Akcja..., s. 80. 
oceny zachowania poszczególnych uczestników, w tym aż trzy punkty poświęcił „Alemu”. Wnioski i konsekwencje, jakie wysnuł z tych ocen, były jednak dla Huskowskiego pozytywne - to, co uznał za błędy, zrzucił na karb „małego doświadczenia bojowego" i dopuścił „Alego” na pełnych prawach do dalszej służby w oddziale. Pamiętajmy, że w czerwcu 1944 r. "Ali” znowu został zastępcą dowódcy akcji likwidacyjnej - nieudanej, ale przygotowanej i przeprowadzonej z niespotykanym wcześniej rozmachem akcji na gen. Wilhelma Koppego w Krakowie. Nie został - co, gdyby uwierzyć w obraz nakreślony u Stachiewicza, byłoby niewątpliwie uzasadnione - odsunięty od działań bojowych i funkcji dowódczych, ponieważ jego predyspozycje psychiczne mogły zagrażać skutecznemu i w miarę bezpiecznemu wykonaniu rozkazów likwidacyjnych. I raport $\mathrm{z}$ akcji na Kutscherę, i pismo przewodnie Adama Borysa wyjaśniają, dlaczego tak się nie stało - dowódca uznał wtedy, że mimo popełnionych błędów „Ali” sprawdził się w boju, że nie było mowy o żadnym „załamaniu”.

Czterdzieści lat później dowódca „Parasola” w rocznicę akcji „Kutschera” udzielił Małgorzacie Rutkowskiej wywiadu, który opublikowany został w „Słowie Powszechnym” 2 lutego 1984 r. Redaktor Rutkowska uważnie i ze zrozumieniem przeczytała, co napisał o udziale Huskowskiego w akcji „Kutschera” Piotr Stachiewicz i zadała w tym kontekście właściwe pytanie:

„[Rutkowska] - No tak, ale ta samodyscyplina nie zawsze zdawała egzamin, przykładem w akcjach «Kutschera» $\mathrm{i}$ «Koppe» postawa «Alego»?

[Borys] - Zdarzały się i takie przypadki, ale wynikały one przede wszystkim ze źle pojętego koleżeństwa i przyjaźni. Znając predyspozycje psychiczne «Alego» nie wolno było wystawiać go do głównych zadań w akcjach. Poza innymi, którzy zostali brakiem jego działania skrzywdzeni on sam został najbardziej skrzywdzony, i to niepotrzebnie.

- To dlaczego Pan, jako dowódca, się na to zgodził?

- Jako dowódca mogłem zawsze nie zgodzić się na wszystko. Ale w imię czego? Dziś wydaje się, że dowódca wiedział wszystko i znał wszystkich swoich podkomendnych. A tak nie było. Ja znałem grono najbliższych moich podkomendnych: dowódców plutonów, służb, łączniczki, adiutanta. Dowódców akcji widziałem parokrotnie w czasie odpraw przed i po akcjach, oglądałem żołnierzy wykonujących akcję również $\mathrm{w}$ czasie odpraw, ale w takich przypadkach trudno powiedzieć, bym tych ludzi znał. Znali ich dowódcy akcji, którzy odpowiadali za słuszny dobór poszczególnych żołnierzy do powierzonych zadań. Reszty żołnierzy nie znałem, ani nawet widziałem"65.

W dalszej części wywiadu pada pytanie, jak Adam Borys postrzegał rolę dowódcy oddziału:

65 M. Rutkowska, O zagrożeniu, etyce i świadomości. Wywiad z Adamem Borysem, „Słowo Powszechne”, 2 II 1984. Dziękuję dr Agnieszce Pietrzak za zwrócenie mojej uwagi na ten wywiad. 
„Rola dowódcy liniowego oddziału wojskowego, zwłaszcza w konspiracyjnej armii podziemnej polegała na umiejętności doboru żołnierzy, opracowaniu i stałym doskonaleniu taktyki walki i wprowadzeniu organizacji gwarantującej optymalne efekty przy minimalnych stratach własnych i współdziałającego z tą walką narodu. Cele te możliwe były do osiągnięcia jedynie przy wysokim morale, nieformalnej dyscyplinie, inicjatywie i samodzielności żołnierzy. Moralna odpowiedzialność dowódcy polegała na precyzyjnej realizacji wyżej wymienionych warunków oraz dbałości o prawidłowy rozwój osobowości młodych żołnierzy w warunkach bezwzględnej i brutalnej walki o byt i przyszłość narodu"66.

Zastanawiająca jest ta zawarta $\mathrm{w}$ jednym krótkim wywiadzie sprzeczność między uchyleniem się od odpowiedzialności za dobór żołnierzy wykonujących akcję a stwierdzeniem, że to właśnie na właściwym doborze ludzi polegała jego rola jako dowódcy oddziału. W 1984 r. w słowach Adama Borysa wyraźnie dostrzec można afirmację tego, co napisał Piotr Stachiewicz. Już we „Wstępie” do swojej książki, analizując fazy przygotowania i przeprowadzenia „specjalnej operacji bojowej”, autor „Parasola” pisał o „całkowitej autonomii, jaką miał dowódca akcji przy ustalaniu jej planu i grupy wykonawczej" oraz o znaczeniu podczas podejmowania decyzji personalnych „więzi łączących dowódcę [akcji] z żołnierzami-kolegami", dodając, że chodzi mu o „sprawę "Alego»"67. Jednocześnie Stachiewicz jakby odczuwał kuriozalność stwierdzenia o „całkowitej autonomii”, jaką miał mieć dowódca akcji względem dowódcy oddziału, bo zapis ten opatrzył przypisem: „Choć może to budzić dzisiaj wątpliwości, jednak dowódca oddziału pozostawiał dowódcy akcji pełną samodzielność w zakresie opracowania planu akcji, a decyzję podejmował przy respektowaniu wniosków przedstawionych przez dowódcę, wyrażając równocześnie swój własny pogląd. Rzadko używał formy rozkazu w tych przypadkach, w których wariant przedstawiony przez dowódcę akcji był możliwy do przyjęcia" 68 .

Słowa Adama Borysa z 1984 r. stoją też w sprzeczności z oceną zawartą w piśmie przewodnim z 1944 r. Kiedy dowódca „Parasola” napisał/powiedział prawdę?

Dokumenty Kedywu KG AK i wypowiedzi po latach Adama Borysa lub ich brak - to fakty. Ich ocena to już interpretacja. Według mnie to nie Adam Borys po latach „mówił Piotrem Stachiewiczem”, ale Piotr Stachiewicz napisał to, co „podyktował” mu Adam Borys.

66 Ibidem.

67 P. Stachiewicz, „Parasol”..., s. 16.

68 Ibidem. 


\section{Adam Borys - dowódca}

Podany wyżej modus operandi stosowany przez Adama Borysa „Dyrektora" kreuje go raczej na swego rodzaju mistrza, mentora, który obserwuje i miękkimi metodami modeluje zachowania oraz decyzje swoich wychowanków, niż na twardego, cieszącego się niepodważalnym autorytetem swoich podkomendnych dowódcę. Na to, że to jednak ten drugi wizerunek odpowiadał prawdzie, jest wiele dowodów przekazanych w relacjach. Przytoczę tutaj jedną, mniej znaną - Zdzisława Dobrowolskiego „Maga” - szefa bezpieczeństwa kompanii „Pegaz”:

„Bezpieczeństwo akcji. Tu rola szefa bezp[ieczeństwa] ograniczała się w praktyce do zorganizowania bezpieczeństwa transportów broni i ruchu samochodów przed i po akcji. Teoretycznie miał on poza tym głos $\mathrm{w}$ sprawie opracowania akcji z punktu widzenia bezpieczeństwa. Zasadniczo nawet było to jedno z głównych zadań szefa bezp[ieczeństwa]. Miał on bowiem prawo zażądać odwołania akcji, jeśli uznał ją za niewystarczająco zorganizowaną lub gdy stwierdził, że nie wykorzystano wszystkich istniejących możliwości celem zapewnienia samej akcji maximum powodzenia, a jej uczestnikom maximum bezpieczeństwa. Mógł zażądać zmian w opracowaniu akcji i w jej organizacji. Miał więc głos w sprawach w oddziale najważniejszych: akcjach.

To wszystko było w teorii. W praktyce wszelka dyskusja, a co dopiero udzielanie rad «Dyrektorowi» było równoznaczne z ośmieszeniem się" ${ }^{\text {. }}$.

W relacji „Maga” zwraca uwagę, że dowódca, który powołał w oddziale funkcję oficera bezpieczeństwa - i całą rozbudowaną strukturę bezpieczeństwa - oraz nadał mu prerogatywy mające być swoistym „bezpiecznikiem”, sam stylem swojego postępowania wobec podkomendnych ten „bezpiecznik" wyłączał. Zemściło się to dramatycznie w planowaniu i później przebiegu akcji na Stamma.

Po wojnie, choć formalnie ustała podległość służbowa z okresu okupacji i powstania warszawskiego, autorytet dowódcy „Parasola” wśród jego ocalałych żołnierzy obowiązywał nadal, a i jego ciężar gatunkowy pozostał taki sam, jaki był w wojennych czasach. Nawiązując świadomie do opinii wyrażonej przez „Maga”, tuż po pierwszym wydaniu „Parasola” Stachiewicza w cytowanym już wyżej liście Marii Wiśniewskiej do Tomasza Strzembosza redaktorka „Kroniki «Parasola»” napisała o Adamie Borysie w kontekście prac nad historią batalionu: „z wyżyn swego Olimpu (urzędował na 3 piętrze przy ul. Hożej w Centrali Przemysłu Jajczarskiego-Drobiarskiego) dowodził batalionem w dalszym ciągu «Dyrektor» - «Pług» - Adam Borys. Jego autorytet był taki sam jak w czasie okupacji, i tak samo jak wtedy

${ }^{69}$ OK, Archiwum „Parasola”, sygn. AW V/2.13, Zdzisław Dobrowolski „Mag”, Zadania i rola szefa bezpieczeństwa, b.m., b.d., s. 1-2, mps. 
w praktyce wszelka dyskusja, a co dopiero udzielanie rad «Dyrektorowi» było równoznaczne z ośmieszeniem się. Przytoczyłam opinię «Maga», Zdzisława Dobrowolskiego, z jego ówczesnej relacji, z którą się absolutnie zgadzam w odniesieniu do lat powojennych"70.

Nie znajduję danych, które wskazywałby, że coś w stylu „zarządzania” swoimi byłymi podkomendnymi zmienił Adam Borys, gdy za pisanie o akcji na Kutscherę i o historii batalionu „Parasol” wziął się Piotr Stachiewicz - żołnierz „Parasola”.

\section{Dlaczego?}

Najprostszą i zamykającą dyskusję odpowiedzią jest oczywiście ta, że dowódca zapomniał o tym, że raport $\mathrm{z}$ akcji na Kutscherę powstał; zapomniał, że został mu przekazany przez Stanisława Huskowskiego „Alego” i zapomniał, że opatrzony jego własnymi ocenami przesłany został do sztabu Kedywu KG AK. Rzecz dotyczy jednak najważniejszej, udanej, legendarnej akcji „Pegaza” i tak fundamentalnych spraw z nią związanych, że tłumaczenie ich deformacji i przemilczeń niepamięcią jedynego człowieka, który znał prawdę - jest dla mnie trudne do przyjęcia.

Przyjrzyjmy się po kolei punktom, w których Adam Borys sformułował swoje oceny przesłane wraz z raportem "Alego” do sztabu Kedywu KG AK, ale zróbmy to krytycznie, nie biorąc za dobrą monetę wszystkiego, co dowódca „Pegaza” napisał.

Ad. 1. Punkt pierwszy wskazuje raczej wyraźnie, że zamek teczki z granatami, którą otrzymał „Ali”, był uszkodzony i wbrew zdaniu Issajewicza wcale nie okazało się później, ,że tę teczkę bardzo lekko można było otworzyć".

Ad. 2. „Ali” nie przejął dowodzenia akcją po zranieniu „Lota”. Dowódca oddziału miał pełne prawo do takiej oceny, ale niezakwestionowana przecież przez niego treść raportu daje podstawy do polemiki. Czytamy w nim, że tylko "Ali” i "Juno” zauważyli sygnał dany do odwrotu przez rannego „Lota” i pobiegli za nim na róg ul. Szopena. Tam „Ali” „ostrzeliwuje bramę i okna domu, w którym schronili się żołnierze [niemieccy]; następnie wraca na róg Alei, aby zobaczyć co się dzieje z resztą ludzi”. To wygląda na zachowanie człowieka, który przynamniej próbuje zapanować nad chaosem. Pamiętajmy, że wszystko rozgrywało się w ciągu kilkudziesięciu sekund krócej, niż mi zajęło napisanie dwóch ostatnich zdań. Poza tym przypomnijmy - pominięte w opracowaniu Stachiewicza - zachowanie "Alego" w kolejnych godzinach i dniach po akcji. 
Ad. 3. Kapitan „Pług” uznał, że „Ali” powinien jechać w aucie z rannymi. Być może tak powinien zrobić, ale co by to zmieniło? Plan przewidywał, że lekarz będzie oczekiwał na auto $\mathrm{z}$ ewentualnymi rannymi na placu Bankowym. Od wejścia do samochodu „Dr. Maksa” - to on podejmował decyzje, które w istocie wskazywały na chaos i brak sensownego planu na wypadek ciężkich zranień uczestników akcji. „Ali” po akcji jedzie tam, gdzie znajduje się ośrodek decyzyjny - czyli do kapitana „Pługa”.

Ad. 4. Zwróćmy uwagę, że na wstępie pisma przewodniego dowódca odnotował, że plan został przez „Lota” opracowany „dokładnie”, żeby teraz - w punkcie czwartym - wytknąć mu braki, na które sam nie zwrócił uwagi na etapie jego układania i zaakceptował. Fakt, że żołnierze wyszli do akcji z niedopracowanym planem, obciąża nie poległego „Lota”, ale Adama Borysa. Jego obowiązkiem było skorygowanie w planie akcji wszystkiego, co uznał w fazie jego układania za błąd - przed wysłaniem ludzi do walki, tym bardziej że zdaniem samego dowódcy konsekwencją tego „zlekceważenia” była strata broni i "prawdopodobnie dwóch ludzi”. Dziwny to zapis, bo wynika z niego, że Adam Borys uznał, że „Juno" i „Sokół” nie zginęliby, gdyby oddali broń łączniczkom. Nie powiązał walki na moście Kierbedzia $\mathrm{z}$ wymuszoną chaosem peregrynacją po Warszawie w poszukiwaniu pomocy szpitalnej dla rannych, która to wędrówka nie byłaby potrzebna, gdyby ta pomoc była adekwatnie zorganizowana - a to obciąża nie „Lota”, ale organizatora i dowódcę oddziału. W tym kontekście wytykanie błędu poległemu jest uchylaniem się od własnej odpowiedzialności ${ }^{71}$.

Ad. 5. Po pół roku walki podległych mu ludzi, po najbardziej spektakularnej z dotychczas przeprowadzonych akcji i jednocześnie największych poniesionych stratach ludzkich dowódca oddziału stwierdza „słabe przygotowanie szpitali na przyjęcie rannych". Kto odpowiada za to, że zabezpieczenie medyczne walczących żołnierzy "Pegaza” nie odpowiadało poziomowi ryzyka, jakie podejmowali? To Adam Borys mówił przecież w wywiadzie dla "Słowa Powszechnego", że to jego zadaniem było „wprowadzenie organizacji gwarantującej optymalne efekty przy minimalnych stratach własnych". Obciążanie „Dr. Maksa” „kardynalnym błędem” odwiezienia rannych do szpitala Przemienienia Pańskiego - w którym pracował - jest znowu uchyleniem się od odpowiedzialności.

Ad. 6. No właśnie - „trzech śmiertelnie rannych” to „Lot”, „Cichy” i „Olbrzymek”, ale „śmiertelnymi” okazały się zranienia dwóch pierwszych.

71 W punkcie czwartym pada stwierdzenie, że dwóch ludzi zostało „przypuszczalnie” straconych. Mariusz Olczak podkreśla w tym miejscu, że Adam Borys miesiąc po akcji nie jest jeszcze przekonany o śmierci „Juna” i „Sokoła”. Moim zdaniem zapis ten wskazuje raczej na wcześniejsze powstanie raportu, a zatem i pisma przewodniego - na tyle wcześniejsze, że dowódca mógł jeszcze nie przesądzać o losie swoich podkomendnych, zob. M. Olczak, Akcja..., s. 80. 
„Olbrzymek”, który otrzymał pomoc najszybciej - przeżył. Nie dowiemy się już, czy obaj zmarli - „Cichy” i „Lot” - przeżyliby, gdyby natychmiast i w warunkach szpitalnych została im udzielona pomoc.

Zwróćmy uwagę, że dowódca w ogóle nie odniósł się do kwestii niedostarczenia broni dla „Alego” oraz wyznaczenia go na zastępcę dowódcy akcji dopiero w drodze na miejsce akcji. Jeżeli „Ali” o tym, że ma pełnić funkcję zastępcy „Lota”, dowiedział się w ostatniej chwili, to pozostali uczestnicy w ogóle mogli nie wiedzieć, kto zastępuje „Lota” w razie jego zabicia lub zranienia.

Żaden ranny - co dowódca podkreśla - nie został na polu walki. Żołnierze wykonali zadanie. Pytanie, czy zwierzchnicy zrobili wszystko, aby ocalić zdrowie i życie swoich podkomendnych już po walce - należy bezwzględnie postawić. Zdaję sobie sprawę, że powyższe stwierdzenia rzucają cień na osobę organizatora i dowódcy oddziału „Agat” - „Pegaz” - „Parasol” - jednego z legendarnych cichociemnych. Jednak nie ja pierwszy formułuje stwierdzenia o zaniechaniach Adama Borysa i próbach uchylenia się przez niego od odpowiedzialności. Dwa przykłady.

Pierwszy to pochodzący z Archiwum Adama Borysa tekst zawarty na jednej stronie maszynopisu i zatytułowany „Błędy dotyczące zabezpieczenia przez Sanitariat akcji «Kutschera». Nie ma autora, ale paginacja - 18 strona - wskazuje, że mamy do czynienia z częścią większej całości, od której ta strona została oddzielona. Przytaczam ten tekst w całości, żeby wskazać, że nie ma on charakteru jednostronnego ataku na dowódcę, ale jest w mojej ocenie próbą obiektywnej analizy działań służby medycznej w akcji „Kutschera”, w której odnotowano także to, czego dowództwo oddziału nie zrobiło przed akcją:

„Błędy dotyczące zabezpieczenia przez Sanitariat akcji «Kutschera»

1. Niedocenienie przez Sanitariat wagi akcji, a przez to nienależyte przygotowanie się do niej. Nie sprawdzono gotowości poszczególnych ogniw w czasie ustawiania się na posterunkach. Moment niedojścia do skutku akcji w ciągu poprzednich 2-ch dni, można było wykorzystać dla kontroli wykonania. Te fakty zemściły się: Szpital Maltański nie zdał egzaminu, skutkiem czego ranni «Lot» $\mathrm{i}$ «Cichy» uzyskali pomoc w późniejszym czasie i byli narażeni na ewakuację bezpośrednio po operacjach. «Sokół» i «Juno» ponieśli śmierć.

2. Konieczność ewakuacji rannych bezpośrednio po zabiegach operacyjnych, nawet $\mathrm{w}$ idealnych warunkach, miała z pewnością ujemny wpływ na rokowanie. Fakt powtórnej ewakuacji rannych dnia następnego z Kliniki dr. Webera był momentem wybitnie szkodliwym.

3. Miejsce wyczekiwania lekarza wybrane było niewłaściwie, gdyż było zbyt dalekie od miejsca akcji a bezpośrednio niemal przy typowanym szpitalu [chodzi o Szpital Maltański, który znajdował się blisko placu 
Bankowego, gdzie na rannych oczekiwał Dr Maks]. Efektem było późne udzielenie pierwszej pomocy.

4. Brak rezerwowego szpitala na wypadek niemożności ulokowania rannych w Szpitalu Maltańskim był poważnym niedociągnięciem. Uważanie szpitala Ujazdowskiego jako stałej rezerwy, w tym przypadku nie mogło mieć miejsca, gdyż szpital ten znajdował się właśnie w bezpośredniej bliskości miejsca akcji.

5. Służba sanitarna nie była orientowana przez d-ctwo o powadze zadania i ewentualnych spodziewanych stratach jak również o przybliżonym zlokalizowaniu akcji.

6. Błędy tej akcji były momentem decydującym o reorganizacji Sanitariatu, w sensie przydzielenia pewnych grup do poszczególnych oddziałów i bezpośrednie podporządkowanie ich d-cy oddziału"72.

Drugi przykład to wypowiedź Wiesława Raciborskiego „Roberta” - kwatermistrza oddziału przez cały okres jego istnienia. Notatka dotyczy nakreślonej w książce Stachiewicza sylwetki Jerzego Zborowskiego "Jeremiego". Interesujący nas fragment komentarza dotyczy do zawartych na 415 stronie pierwszego wydania książki dywagacji autora o niezasadności wyznaczenia "Alego" na zastępcę dowódcy akcji „Koppe” i stwierdzenia, że to „Jeremi” - kierując się zasadami koleżeństwa i nie uświadamiając „sobie w pełni ryzyka” - zaakceptował tę kandydaturę: „Rozważania nad trafnością wyboru z-ców dow[ódców] są moim zdaniem co najmniej zbędne. Jeżeli zaś prawdą jest to, co zostało napisane o "Alim», to powstaje pytanie: dlaczego «Dyrektor» akceptował ten wybór? Nasuwa mi się nawet pytanie ogólniejsze: dlaczego «Pług» akceptował wszystkie propozycje «Jeremiego»? Czyżby popadł w kompleks niższości widząc tę energię, pomysłowość i narastające doświadczenie bojowe «Jeremiego» - jeżeli w gruncie rzeczy był innego zdania odnośnie w[yżej] w[ymienionych] spraw - a może to było asekurowanie się przed odpowiedzialnością w przypadku nieudania się akcji. (Odpowiedzialność, którą np. powinien ponieść «Pług» po akcji «Stamm»)"73. Odnotujmy gwoli prawdy, i wyrażając jednocześnie przekonanie, że ta prawda rzadko kiedy bywa prosta, inne słowa „Roberta” z tego samego tekstu: „Jeżeli d-ca nie przekazuje swej wiedzy swemu zastępcy to jest to zły d-ca, a takim «Pług» nie był"74.

72 Archiwum Adama Borysa, Błędy dotyczące zabezpieczenia przez Sanitariat akcji „Kutschera”, b.m., b.d., mps.

73 Archiwum Rodzinne W. i Wandy Pietraszewiczów, Wiesław Raciborski ps. „Robert”, Uwagi dotyczące Jerzego Zborowskiego pseudonim „Jeremi” z-cy d-cy bat. „Parasol”, którego sylwetka opisana jest w książce pt. „Parasol” Piotra Stachiewicza, b.m. 10 VI 1982 r., s. 2, mps. Dziękuję pani Marii Dubiczyńskiej za udostępnienie maszynopisu.

74 Ibidem, s. 1. 
We „Wstępie” do swojej książki Piotr Stachiewicz napisał: „Z punktu widzenia użyteczności społecznej historyk może i powinien w określonym przez siebie momencie uznać, że zebrany przez niego materiał źródłowy pozwala mu podjąć się opracowania syntetycznego i przekazania go czytelnikom. Fakt ten nie wyklucza jednak możliwości dalszego uzupełniania bazy źródłowej, której poszerzenie nie powinno jednak zburzyć raz przedstawionej syntetycznej konstrukcji opracowania, lecz jedynie ją wzbogacić. Im zaś w mniejszym stopniu ją wzbogaci, tym rzetelniejsza była praca pierwotna”75. Akcja „Kutschera” i „sprawa «Alego»" okazały się „miękkim podbrzuszem" książki Piotra Stachiewicza. Przemilczane przez Adama Borysa, a ujawnione $\mathrm{w}$ ostatnich latach dokumenty nie wzbogaciły „konstrukcji opracowania”, ale właśnie ją „zburzyły”.

75 P. Stachiewicz, „Parasol”..., s. 16-17. 


\section{ANEKS}

$\mathrm{P}[$ ega $] z-\mathrm{B}[\mathrm{ryl}]$

Alarmowo!

2.2 .44

p. Nil

Melduje, że we wtorek dn. 1.II godz. 9.10 został zastrzelony pan K[utschera] przed swoim biurem. D-ca akcji Lot, wykonawca 2-gi Kruszynka. Atak na posterunek i budynek: Juno i Ali, ubezpieczenia: Cichy i Olbrzym, szofer, który zatarasował drogę - Miś, oraz Szoferzy: Sokół i Bruno. W czasie akcji zostali ciężko ranni: Lot, Cichy i Olbrzym; lżej ranny Miś, ponadto w czasie powrotu ze szpitala przez most Kierbedzia, został zabity przez żandarmerię Sokół i przypuszczalnie zabity, względnie w rękach żandarmerii Juno. Straty broni: 3 steny, $1 \mathrm{Pm}$. 40 i około 8 sztuk pistoletów. Straty n-pla: 1 generał, przypuszczalnie 4 żandarmów. Poza tym utraciliśmy 2 samochody. Wskutek umieszczenia Lota i Cichego w szpitalu, w którym urzęduje policja i G[estap]O., zmuszony byłem przeprowadzić akcję ewakuacyjną rannych po operacji o godz. 19.30.

Wobec bardzo dużych strat w broni maszynowej i krótkiej proszę o przydzielenie mi 10 sztuk broni maszynowej, oraz o zezwolenie na kupno 20 szt. broni krótkiej, celem umożliwienia mi prowadzenia dalszych moich zadań. Zespół wykonywujący akcję zasługuje na najwyższe uznanie, przyczem ranni mimo śmiertelnych ran zdołali o własnych siłach dojść do samochodów i ewakuować się z miejsca akcji.

2) ze sfer zainteresowanych proszę o nie umieszczanie nazwiska Podhoreckiej (Pawiak) w B[iuletynie] I[nformacyjnym]. Grozi to represjami dla personelu polskiego na Pawiaku.

Źródło: AAN, Akta Piotra Stachiewicza, sygn. 2, Meldunek Bryla do Nila, b.m.

Tekst ten był cytowany przez Stachiewicza, jednak niedokładnie i nie w całości pominięto, co nawet zrozumiałe, część drugą meldunku, ponieważ nie dotyczyła akcji na Kutscherę, ale reperkusji po likwidacji 29 stycznia 1944 wachmajsterki Jadwigi Podhorodeckiej (w meldunku błędnie „Podhorecka”, co w innym miejscu swojej książki - przytaczając - Stachiewicz poprawił): P. Stachiewicz, „Parasol”..., s. 341.

Raport „Alego” został opublikowany: H. Piskunowicz, Zamach na Kutscherę $w$ świetle raportu Stanisława Huskowskiego („Ali”), WPH 1993, nr 2, s. 190-195. Tekst ten można znaleźć na stronie: http://www.rawelin.foxnet. pl/zopa/alikut.htm. Piskunowicz umieścił przypisy do pseudonimów, które rozszyfrował na końcu. 


\section{Bibliografia}

\section{Archiwalia}

Archiwum Adama Borysa

Archiwum Akt Nowych

Akta Adama Borysa

Akta Piotra Stachiewicza

Zespół Akt Konspiracyjnych

Ośrodek „Karta”

Archiwum „Parasola”

Archiwum Rodzinne W. i Wandy Pietraszewiczów

List Kazimierza Krajewskiego i Tomasza Łabuszewskiego do Waldemara Stopczyńskiego z 18 II 2013, w posiadaniu Waldemara Stopczyńskiego.

List Marii Stypułkowskiej-Chojeckiej do Waldemara Stopczyńskiego, mps, Warszawa, 6 III 2008, w posiadaniu Waldemara Stopczyńskiego.

\section{Opracowania}

Bratny R., Kolumbowie rocznik 20, Warszawa 2016.

Dunin-Wąsowicz M., Polemika z grupa „Parasol”, „Nowa Kultura” 1957, nr 24, s. 7.

Dunin-Wąsowicz M., Zamach na Kutschere, Warszawa 1958.

Dylawerska M. et al., Akcja na Kutscherę, „Wojskowy Przegląd Historyczny” 1959, nr 4, s. 84-121.

Kamiński A., „Zośka” i „Parasol”. Opowieść o niektórych ludziach i niektórych akcjach dwóch batalionów harcerskich, Warszawa 2009.

Maciorowski M., Teczka „Alego”, „Ale Historia” dodatek do „Gazety Wyborczej” 2014, nr 5, s. 12-13.

Olczak M., Akcja na Kutschere - nowe ustalenia, „Biuletyn Informacyjny ŚZŻAK” 2016, nr 2, s. 77-81.

Piskunowicz H., Zamach na Kutschere w świetle raportu Stanisława Huskowskiego („Ali”), „Wojskowy Przegląd Historyczny” 1993, nr 2, s. 190-195.

Poradzki Z., Zamach na Kutschere, „Rzeczpospolita”, 10 II 1947.

Rutkowska M., O zagrożeniu, etyce i świadomości. Wywiad z Adamem Borysem, „Słowo Powszechne", 2 II 1984, s. 3.

Srocki B., Bronisław Pietraszewicz - organizator zamachu na Kutscherę, „Za Wolność i Lud" 1956, nr 8, s. 9-11.

Stachiewicz P., Akcja „Kutschera”, Warszawa 1982.

Stachiewicz P., Akcja „Kutschera”, „Więź” 1975 nr 7-8, s. 114-135.

Stachiewicz P., „Parasol”. Dzieje oddziału do zadań specjalnych Kierownictwa Dywersji Komendy Głównej Armii Krajowej, Warszawa 1981.

Stopczyński W., O „Raporcie Alego z akcji na Kutscherę” - odpowiedź na polemikę dr Marii Wiśniewskiej, „Przegląd Historyczno-Wojskowy” 2012, nr 2(240), s. 161-172.

Stopczyński W., Teczka pełna granatów, „Kombatant” 2009, nr 3, s. 3-9.

Stopczyński W., W kręgu Bolesława Srockiego. Ludzie „Petu”. Relacje - wspomnienia polemiki, Gdańsk, 2016.

Wiśniewska M., Na marginesie artykułu Waldemara Stopczyńskiego „Teczka pełna granatów”, „Przegląd Historyczno-Wojskowy” 2011, nr 4(237), s. 221-224. 
Wiśniewska M., „Parasol” po czterdziestu latach, „Przegląd Powszechny” 1982, nr 1/2, s. $128-138$.

\section{Źródła internetowe}

Stopczyński W., Jedna minuta i czterdzieści sekund, http://www.gfo.iq.pl/gag/images/ stories/raport_alego/1.40sek.pdf [dostęp: 16 VIII 2018].

Stopczyński W., „Zamach na Kutscherę”, czyli IPN-u kłopot z raportem „Alego”, https://histmag.org/Zamach-na-Kutschere-czyli-IPN-u-klopot-z-raportemAlego-16326/1 (dostęp 29 VII 2018).

Uzarek K., Wilkowska G., Lekcja judo, http://www2.polskieradio.pl/wojna/posluchaj. aspx?sid=4 (dostęp 16 VIII 2018).

\section{STRESZCZENIE}

\section{Waldemar Stopczyński, Raport „Alego” z akcji na Kutscherę, czyli czego nie powiedział dowódca batalion Parasola}

Zlikwidowanie Franza Kutschery przez żołnierzy I plutonu kompanii „Pegaz” (późniejszy batalion „Parasol”) to jedna z najbardziej znanych akcji zbrojnych polskiego podziemia. Powojenna narracja o wydarzeniach z 1 lutego $1944 \mathrm{r}$. oparta była do lat dziewięćdziesiątych XX w. na relacjach tych uczestników akcji, którzy przeżyli wojnę oraz na kilkuzdaniowym meldunku przesłanym przez dowódcę „Pegaza” do płk. „Nila”, a spetryfikowana została książką Stachiewicza „Parasol”. Opublikowane w 1993 i 2016 r. dokumenty - raport zastępcy dowódcy akcji „Kutschera” oraz pismo przewodnie dowódcy „Pegaza” do niego dołączone - zakwestionowały tę narrację. W artykule prześledzono, jak kształtowała się opowieść o akcji na „kata Warszawy", wskazując, że dowódca zaakceptował tę jej wersję, w której jest najwięcej rozbieżności w stosunku do zapisów w dokumentach z okresu konspiracji.

Słowa kluczowe: Adam Borys „Bryl”, „Pług”, Stanisław Huskowski „Ali”, Raport „Alego”, Piotr Stachiewicz, Franz Kutschera, Kedyw, „Agat”, „Pegaz”, „Parasol”

\section{SUMMARY}

\section{Waldemar Stopczyński, „Ali's” report on the operation against} Kutschera - what the commander of the „Parasol” battalion did not reveal

The elimination of Franz Kutschera by the soldiers of the 1st platoon of the „Pegasus" company (later the „Parasol” battalion) is one of the most famous military actions of the Polish underground. Until the 1990s, the post-war narrative about the events of February 1, 1944 was based on the accounts of those participants of the operation who survived the war and on a brief report sent by the commander of „Pegasus” to Colonel „Nil”, and it was consolidated by P. Stachiewicz's book „Parasol”. The documents published in 1993 and 2016 - the report of 
the deputy commander of the "Kutschera” operation and the cover letter of the commander of "Pegasus" attached to it - questioned this narrative. The article traced the development of the story about the operation against the „executioner of Warsaw”, indicating that the commander accepted this version which contained the most discrepancies in comparison with the records in the conspiracy period documents.

Keywords: Adam Borys „Bryl”, „Pług”, Stanisław Huskowski „Ali”, „Ali’s” report, Piotr Stachiewicz, Franz Kutschera, Kedyw, „Agat”, „Pegaz”, „Parasol”

\section{РЕЗЮМЕ}

Вальдемар Стопчинский, Рапорт „Али” по операции на Кутчеру, или О чем не сказал командир батальона „Парасоль”

Ликвидация Франца Кутчера солдатами 1-го взвода роты „Пегаз” („Pegaz”; позднее - батальон „Парасоль”/„Parasol” - прим. пер.) - это одна из наиболее известных вооруженных операций польского подполья. Послевоенное толкование событий 1 февраля 1944 года основывалось до 90-х гг. ХХ вв. на воспоминаниях тех участников операции, которые пережили войну, а также на отчете, состоящим из нескольких фраз, присланным командиром „Пегаза” полковнику „Нила”. Оно также нашло свое подтверждение в книге П. Стахневича „Парасоль”. Опубликованные в 1993 г. и 2016 г. документы - отчет заместителя командира операции „Кутчер” и сопроводительное письмо командира „Пегаза”, прилагаемое к этому отчету, - ставят под сомнение такую интерпретацию событий. Данная статья показывает, как изменялось описание операции в отношении „палача из Варшавы”, а также указывает на то, что командир принял ту ее версию, в которой было наибольшее количество расхождений в отношении записей в документах периода конспирации.

Ключевые слова: Адам Борис „Брыль”, „Плуг”, Станислав Хусковский „Али”, рапорт „Али”, Петр Стахневич, Франц Кутчера, „Кедыв”, „Агат”, „Пегаз”, „Парасоль” 